\title{
OS DILEMAS DO USO DA FOTOGRAFIA NA RESTITUIÇÃO DA PALAVRA DO OUTRO: UM ESTUDO SOBRE IMAGEM E MEMÓRIA NA BARRA DO OURO - RS
}

\author{
Fernanda Rechemberg \\ Ana Luiza Carvalho da Rocha (Orientação.)
}

\section{Introdução}

Este trabalho é resultado das inquietações que perpassavam meu trabalho como fotógrafa e minha formação como jornalista. Especialmente no que tocava ao diálogo e à relação com "as fontes" ou os sujeitos das matérias jornalísticas, percebia que um certo modo de fazer próprio dos jornalistas muitas vezes desrespeitava ou ignorava essa relação. Buscando amparo no campo da antropologia, encontrei uma linha de diálogo entre as duas áreas, ainda que tênue e pouco explorada. As "fontes" passaram a ser o Outro; o jornalista, o antropólogo; e a matéria, a etnografia.

Num momento em que o estatuto da imagem é cada vez mais discutido, me pareceu crucial levantar, nesta monografia, a questão do consumo da imagem do Outro. Para isso, busco apresentar a problemática do fotojornalismo frente à esse consumo e suas possibilidades, em um diálogo estreito com a antropologia, de restituir a palavra e a imagem desse Outro.

A experiência de "estar em campo" foi fundamental para a construção deste diálogo. Enquanto jornalista pude experimentar uma nova maneira de contar uma estória, imbuída de preocupações e metodologias caras à antropologia. O distrito de Barra do Ouro - RS foi o campo desta pesquisa, onde busquei, junto aos velhos narradores do lugar, restituir sua voz e imagem.

Inicio este trabalho apresentando alguns dos conceitos pertinentes à questão do consumo de imagens, segundos os quais a fotografia e o fotojornalismo constroem suas bases. Em seguida, convido o leitor a entrar comigo em campo e refletir sobre os pontos de diálogo e confronto entre a antropologia e o jornalismo, na medida em que me torno uma jornalista imbuída de preocupações e metodologias caras à antropologia. As "fontes" ou os "narradores" que compõem a narrativa deste trabalho são aqui apresentados. No terceiro 
capítulo, busco aproximar o leitor do meu campo, compondo uma etnografia da Barra do Ouro, que pretende deixar de lado a objetividade e a impessoalidade característica das matérias jornalísticas. As questões relativas à fotografia e memória são discutidas no quarto capítulo, onde costuro conceitos relativos à memória e suas imagens, e à ocasião da velhice. Por fim, retorno minhas imagens à esses velhos, buscando um diálogo entre passado e presente.

\section{Amarrando o diálogo entre fotojornalismo e antropologia}

A obtenção e o consumo de imagens vem aumentando sistematicamente desde o surgimento da fotografia, em meados do século XIX. Seja na ilustração de uma notícia, num outdoor publicitário ou nas mãos de alguém que relembra um ente querido, as imagens fotográficas nos circundam e nos inquietam, por um caráter mágico que, mesmo passado mais de um século de seu surgimento, ainda permanece.

Não é à toa que ainda hoje, mesmo com o aumento das discussões acerca de sua objetividade, a imagem fotográfica continue sendo, a senso comum, vista como "verdadeira", e o fotógrafo, como "testemunha". Nascida em um ambiente positivista, a fotografia se desenvolveu em um momento histórico em que a crença no fato e na verdade era indiscutível. Assim, a fotografia acabou por desempenhar o papel de prova, registro, sendo utilizada pela ciência, pelos governos, pela indústria, e principalmente pelas organizações noticiosas, que adotavam com a ajuda da imagem fotográfica o discurso da objetividade jornalística.

Para Jorge Pedro Sousa (2000), no livro em que faz um traçado histórico do fotojornalismo no Ocidente, o surgimento da televisão e dos meios multimídia proporcionou um aumento no número e na diversidade de imagens passíveis de cumprir o papel de representação do mundo. Com isso, a autoridade do fotojornalismo na representação do real foi reduzida, abrindo-se um caminho para que explorasse novas funções e usos sociais. O aspecto ficcional e interpretativo da fotografia foi ganhando espaço na prática e nas discussões, quando "vários fotojornalistas começaram, (...), após a Segunda Guerra Mundial, a reivindicar e praticar o seu direito à subjetividade assumida, 
encarando a fotografia não como o 'espelho do real', mas mais como uma metáfora ou até uma metáfora-metonímia da realidade" (2000, p.222).

O surgimento das câmeras digitais, que já substitui a utilização do negativo em grande parte dos veículos jornalísticos, contribuiu para a relativização da noção de fotografia enquanto documento. A idéia de que a fotografia consiste em uma manipulação visual da realidade é radicalizada na imagem digital. Se no processo analógico a imagem passa pelo controle da exposição e velocidade, pela escolha do foco, revelação, procedimentos de laboratório e impressão, essas são técnicas até certo ponto visíveis na imagem. É possível detectar uma fotografia manipulada em laboratório sem muitas dificuldades. Com a imagem digital, o fotógrafo pode alterar a cor de um cabelo, tirar uma pessoa ou objeto da cena, criar situações inverossímeis ou mesmo falsas, como o encontro entre duas pessoas que nunca se viram, sem que essa manipulação se faça necessariamente visível. Essa tecnologia vem sendo muito utilizada por fotógrafos amadores, o que de certa forma amplia a discussão acerca da manipulação da imagem para um número cada vez maior de pessoas, e que são, genericamente, os espectadores das imagens produzidas no fotojornalismo. Para Flávio Cauduro (1998, p.86), o advento da fotografia digital torna mais transparente o processo de construção da imagem fotográfica, libertando a fotografia tradicional de seu compromisso com a objetividade. Nesse sentido, a elaboração de um código de ética no fotojornalismo e na fotografia em geral se faz necessária (Sousa, 2000; Guran, 1992), retificando um compromisso ético e uma nova relação de confiança entre fotojornalistas e o público, bem como entre fotógrafos e sujeitos fotografados.

Acompanhando a crescente discussão acerca da objetividade da imagem, a fotografia hoje pede um sentido maior de autoria e de sinceridade sobre as circunstâncias nas quais é produzida. As tensões permanentes que envolvem a produção e a interpretação da imagem fotográfica, sejam elas de cunho social, ideológico, econômico, histórico e mesmo tecnológico, raramente se fazem visíveis. É como se um aspecto mágico da fotografia fosse perdido ao se revelar essas tensões. No entanto, a magia da fotografia, bem como de qualquer imagem, reside em sua natureza simbólica. Ela oferece ao leitor um espaço interpretativo, onde o olhar vagueia de modo circular: os elementos são constantemente vistos e revistos, até que o leitor possa compôr um sentido para a imagem, sentido esse que muda e se enriquece a cada novo olhar sobre a mesma fotografia. 


\section{A fotografia como documento: desfiando vozes e olhares em silêncio}

Em "Pequena história da fotografia", Walter Benjamin elucida o que de novo e estranho surgiu com a fotografia, e que não estava expresso na pintura. Diante do retrato de uma mulher, afirma haver "algo que não pode ser silenciado, que reclama com insistência o nome daquela que viveu ali" (1994, p.93). Com o tempo, as pinturas podem se reduzir ao talento artístico de seu autor, deixando a um segundo plano a identidade do que foi retratado. A fotografia não nos permite o esquecimento: a imagem impressa sempre nos interroga sobre a situação, pessoa ou paisagem que estão ali retratadas.

As primeiras pessoas a serem fotografadas apareciam nas imagens sem que nada se soubesse sobre suas vidas, sem nenhum texto que as identificasse. $\mathrm{O}$ rosto dessas pessoas era envolto em silêncio (Benjamin, 1994, p.95). A época, o impacto de ver a imagem de uma pessoa reproduzida era sem dúvida muito mais forte que hoje, passadas décadas de avanços tecnológicos no campo da imagem. Mas especialmente nos retratos de pessoas, a imagem fotográfica ainda guarda consigo a força e a proposta de um reconhecer-se e um estranhar-se.

Nos primórdios da fotografia, a maior parte das pessoas não sabia o que era aquela máquina, não entendia a câmera e o processo fotográfico, e não podia imaginar que daquele aparelho sairia sua imagem refletida. Walter Benjamin, ao falar sobre o estranhamento diante das primeiras fotografias, cita o fotógrafo Dauthendey: "as pessoas não ousavam a princípio olhar por muito tempo as primeiras imagens por ele produzidas. A nitidez dessas fisionomias assustava, e tinha-se a impressão de que os pequenos rostos humanos que apareciam na imagem eram capazes de ver-nos, tão surpreendente era para todos a nitidez insólita dos primeiros daguerreótipos” (1994, p.95).

O excessivo consumo de imagens do Outro que assistimos hoje possui raízes históricas e revela um pouco da curiosidade do homem acerca de si mesmo. Quando os primeiros fotógrafos saíam em expedições pelo mundo à procura de imagens do diferente e do exótico, buscavam, ainda que para usos e finalidades distintas - desde a expansão colonialista até a comercialização em postais -, um reconhecimento da imagem do Outro. De acordo com Sousa (2000, p.27), a primeira revista ilustrada publicada em 1842 em Londres, teve em poucos anos sua tiragem aumentada de 200 para 300 mil exemplares, 
indicando uma crescente apetência social pela imagem. Da mesma forma, a fotografia era utilizada por antropólogos afim de registrar povos exóticos e ditos "primitivos". Esses fotógrafos-viajantes que buscavam testemunhar aquilo que viam, ambicionando substituir o leitor na leitura visual do mundo, já propunham uma retórica da objetividade da imagem.

Nesse sentido, um aspecto documental da fotografia sempre esteve presente. Ela vem retratando, ao longo do tempo, a história visual de indivíduos e sociedades, seja no fotojornalismo, na publicidade, na arte ou na pesquisa. Através do olhar de um grupo/indivíduo sobre outro e sobre si mesmo, o que vemos não é apenas a imagem documentada no papel, mas a forma na qual o Outro é representado, tornando possível uma compreensão das sociedades em determinada época e de seu olhar sobre si mesmas.

\section{O narrador e a restituição da palavra do Outro}

Os registros visuais fotográficos ou fílmicos se constituíram ao longo do séc. XX, em um meio de perpetuar as diferentes formas de viver e pensar de indivíduos e grupos, geralmente como instrumento de registro das vozes dos grupos humanos em processos de extinção ou de aculturação. Entretanto, as imagens que foram, e ainda são captadas deste Outro, podem permanecer em silêncio encerradas apenas no interior da narrativa daquele que as capturou, sem a preocupação com a restituição da voz dos sujeitos fotografados. Tomados nesse contexto, os comentários de Benjamin (1994) a respeito da morte da figura do narrador e o fim da arte de narrar na Modernidade, em um clássico artigo sobre a obra de Nicolai Leskov, são elucidativos sobre a problemática lançada por esta monografia sobre o lugar do ato fotográfico no jornalismo e as possibilidades da restaurar a voz desse Outro

Traçando alguns comentários críticos sobre o romance moderno, para Walter Benjamin, narrar não é contar uma história simplesmente. $\mathrm{O}$ narrador é aquele que comunica experiências, que transmite sua sabedoria e seus ensinamentos na forma de estórias, de narrativas. Essas estórias são passadas de pessoa a pessoa, em uma forma artesanal de comunicação, e sempre guardam em si uma dimensão utilitária para a vida daquele que escuta. A narrativa clássica, ao contrario do que aponta o romance moderno, seria, portanto, entremeada pela memória. Benjamin (1994, p.205) menciona que contar histórias sempre foi a arte de contá-las de novo, e portanto, se, na Modernidade, as histórias 
não são mais conservadas, se a memória não registra essas histórias e o próprio sentido de passá-las adiante, elas se perdem.

Para Benjamin, na Modernidade, o nascimento de toda uma industria cultural, onde poderia encaixar as atuais mídias, faz com que a figura do narrador esteja cada vez mais distante de nós. "É a arte de narrar que está em vias de extinção", diz o autor, referindo-se à perda, no momento atual, de uma faculdade tão antiga quanto fundamental ao homem: a faculdade de intercambiar experiências (1994, p.198). Em especial, Benjamin aponta o surgimento de uma nova forma de comunicação, a informação, como responsável pelo definitivo declínio da arte de narrar. Assim, as narrativas teriam se transformado em mera informação, de caráter impessoal e cada vez mais distante da experiência.

Ainda segundo o autor, uma das principais diferenças entre a narrativa e a informação é que a primeira trabalha com o miraculoso, o surpreendente, aquilo que não possui nem deve possuir explicação, enquanto a segunda afirma suas bases em cima do plausível, do fato, explicando-o, traduzindo-o e interpretando-o para que seja uma informação completa e eficaz. Na informação, sobra pouco espaço para que o leitor construa sua interpretação, por isso a narração tem uma amplitude que não existe na informação (1994, p.203).

De fato, é tamanha a quantidade de informações que recebemos todos os dias pelos meios de comunicação que nos vemos obrigados a esquecê-las, para ceder espaço às novas. Principalmente porque a informação jornalística se traduz no fato em si, ela requer e proporciona uma compreensão imediata. Assim se justificam sua rapidez, impessoalidade, e seu esquecimento. A própria expressão "a título de informação" já nos diz alguma coisa: quando a escutamos, sabemos que aquilo que vem depois não é importante ou imprescindível para nós, mas apenas algo "informativo", que complementa.

Sem dúvida a informação foi tomando um espaço na vida das pessoas que originalmente pertencia à narrativa. A confusão ética e moral em que hoje nos encontramos pode ser explicada pela ausência da narrativa enquanto possibilidade norteadora do comportamento humano, no sentido de lhe transmitir ensinamentos ético-morais, aconselhamentos e sugestões práticas. Neste ponto vale retomar Benjamin e suas reflexões sobre o fim da arte de narrar na Modernidade, quando o autor se indaga se não seria justamente tarefa do narrador "trabalhar a matéria-prima da experiência - a sua e a dos 
outros - transformando-a num produto sólido, útil e único”(1994, p.221). Entretanto, ainda que, como pontua Benjamin, a informação pareça ter substituído a narrativa, na medida em que tomou para si uma comunidade de ouvintes que antes fazia eco à voz do narrador, é importante que se assinale que elas cumprem papéis essencialmente diferentes. Para o caso que trata minha monografia, acredito ser o equilíbrio entre a informação e a narração que pode restituir a voz aos narradores e a escuta aos ouvintes, sem que se faça necessário excluir uma em favor de outra. Neste ponto, acredito que não há como retroceder no lugar que ocupa a mídia na contemporaneidade no avanço e na difusão da informação; mas sim, trata-se de se relativizar a validade desta no papel que é e sempre foi caro ao narrador.

De qualquer forma, algumas décadas se passaram desde as afirmações de Walter Benjamin, e o que se pode constatar é que a narrativa e a figura do narrador não foram extintas, ao contrário. Aproximando a figura do narrador à pequena realidade que nos circunscreve, encontramos narradores em nossos avós, pais, tios, naqueles velhos conhecidos que chegam sempre com algo a dizer. Ainda existem narradores em busca de quem os escute, ainda existe em nós, jornalistas, a semente de continuidade que habita todo narrador. É preciso que lhes emprestemos nossos ouvidos e nossa atenção, que tenhamos o interesse em conservar o que nos foi narrado em nossa memória para que o narrador continue a existir, naqueles que escutamos e em nossa própria voz.

A arte de narrar, portanto, subsiste nas modernas sociedades complexas urbanoindustriais, cumprindo finalidades e sentidos outros, mas que retomam, de alguma forma, alguns postulados benjaminianos a respeito da arte de narrar. Para Rocha e Eckert (no prelo), o antropólogo, no estudo etnográfico das diferentes formas de vida social nas grandes cidades e no registro das trajetórias e itinerários dos grupos urbanos acaba, ele próprio, se transformando na figura do narrador. Ao escrever sobre a experiência de vida de um grupo/comunidade pesquisada, assim como sobre sua própria experiência de campo, o antropólogo atua como um depositário da memória e do modo de vida do Outro. A arte de narrar, dessa forma, tem garantida sua continuidade, na medida em que o antropólogo transpõe a fala desse grupo narrando suas histórias vividas, seja por meio do texto escrito, sonoro ou visual. Nas palavras das autoras, "por sua condição de guardiões da memória a escrita, assim como os registros sonoros e visuais, ao fixarem os traços da tradição dos 
grupos estudados pelos antropólogos, no papel ou na película, influenciam a re-atualização e re-transmissão de tais traços além de gerar novas tradições" (Rocha e Eckert, no prelo ).

Da mesma forma, o trabalho do jornalista/fotógrafo também pode ser entendido como uma transposição da voz do Outro, e para uma comunidade bem mais ampla que a dos antropólogos: os veículos de comunicação. Ainda que a mídia de modo geral se caracterize pela transmissão de informação, não precisa, necessariamente, se reduzir a ela: essa tradução de diferentes modos de vida pode ir além da simples informação, constituindo-se como uma forma de narrativa.

Em ambas as situações, especialmente pela veracidade atribuída ao suporte técnico que ampara essas novas modalidades de narrar (imagem e som), o caráter testemunhal desses registros revela um compromisso com o destino do grupo/comunidade retratado.

\section{O olhar fotográfico}

Mesmo entendendo que o significado de uma imagem é elaborado subjetivamente, isso não exclui o papel e a intencionalidade do fotógrafo. É justamente o encontro da intenção do fotógrafo com a subjetividade do leitor que constitui o significado da imagem. Como afirma Koury (apud Diniz,1998), "a imagem significa, ao mesmo tempo, o olhar do criador e o olhar do espectador, e a interpretação é resultante dessa interdependência, ou dessa ambigüidade de olhares". O resultado desse encontro é uma síntese entre o evento representado e as interpretações construídas sobre ele, o que coloca a fotografia como uma representação peculiar da realidade.

A obtenção de uma imagem é fruto de uma experiência humana, ou seja, do olhar e o sentimento do homem por trás da lente, que dão à cada fotografia um caráter singular e intencional, podem tomar múltiplas direções. Principalmente no que diz respeito ao uso da imagem no fotojornalismo, essa informação é muitas vezes direcionada para finalidades específicas, coerentes com o discurso do veículo de comunicação. Nesse sentido, podemos falar de uma outra forma de manipulação que não a manipulação da imagem em si, por processos óticos, químicos ou digitais, mas de seu conteúdo.

Entretanto, conforme Leite (2001), se os fotógrafos manipulam suas fotografias, também os cientistas sociais estabelecem aquilo que deve ser visto. Em ambas as situações, a utilização de legendas; o espaço e contexto dado à fotografia na elaboração de um jornal, 
livro, folheto ou exposição; a edição das imagens que o pesquisador retorna ao sujeito fotografado e mesmo seu discurso ao retornar essas imagens são algumas formas de dirigir o olhar do leitor, demonstrando uma necessidade por parte de quem produz a imagem de focar e delimitar o seu sentido, que é por natureza, circular e dispersivo.

No entanto, a intenção do fotógrafo/pesquisador confronta-se com a intenção do leitor: com sua disposição para apreender o significado daquela imagem, com sua experiência de vida, com seus aspectos particulares e subjetivos. Esse confronto torna ingênua a idéia de que uma pessoa possa ser manipulada ao ler imagens, sendo levada à compreender o significado da imagem tal como este lhe é sugerido. O que acontece é que na maior parte das vezes não há espaço para esse confronto: as imagens já vem com uma interpretação pronta, o que pode ser entendido pelo leitor como um ponto final na significação dessa imagem.

Podemos pensar em uma distinção entre a imagem acompanhada de interpretação da imagem acompanhada de informação, seja em seu próprio conteúdo imagético ou no texto no qual ela está inserida. Enquanto a primeira encerra o significado da imagem, a segunda o amplia, trazendo novos elementos para sua compreensão. De modo geral, no fotojornalismo e nas Ciências Sociais, distingue-se a foto boa da foto ruim pela possibilidade que aquela apresenta de transmitir com clareza determinada informação, o que a configura como uma foto "eficiente" (Guran, 1992).

Nesse sentido, o conceito de informação que melhor se enquadra neste trabalho é o proposto por Sousa (2000, p.224) que vê a informação como possibilidade de "gerar conhecimento profundo, contextualizar, ajudar a perceber e fomentar a sensibilidade dignificadora para com o ser humano, a Terra e os seus problemas”.

\section{O fotojornalismo e o problema do consumo da imagem do Outro}

De uma forma geral, o jornalista possui um comprometimento e uma responsabilidade com o veículo para o qual escreve ou fotografa, com a qualidade estética e de conteúdo do texto ou da imagem. Eugênio Bucci (2000), escrevendo sobre a questão da ética na imprensa, coloca que esse mesmo compromisso - dos jornalistas com a empresa e da empresa jornalística na contratação de bons profissionais - deve ser devolvido para o público. Mas o compromisso com a pessoa que se constitui no tema da matéria/reportagem 
raramente é mencionado quando se discute ética no jornalismo. Já é pouca a bibliografia que trata desse tema; na fotografia e no fotojornalismo esse número é ainda menor, e normalmente se refere à manipulação das imagens e seu uso indevido no momento da publicação, e não à relação fotógrafo-fotografado.

Ainda no campo das articulações entre ética e jornalismo, vale à pena assinalar os comentários de Orlando Brito, fotógrafo que registra cenas da política brasileira, sobre o compromisso com o ato de fotografar:

Estou falando do momento de fazer a foto: eu faço, não tenho compromisso com nenhuma das partes que estão à minha frente. Não sou polícia nem ladrão. Meu compromisso é com o que aconteceu e com o leitor. Tenho de ter independência para isso, senão estarei omitindo talvez a parte mais importante daquela realidade.

Alguns autores afirmam que o jornalismo é, por si só a realização de uma ética, ou ainda, que afirma-se pela ética, na medida em que busca a verdade dos fatos (Bucci, 2000, p.41). Essa autoridade que o jornalismo tem na busca por aquilo que está escondido mas que o cidadão tem o direito de saber pode justificar atitudes que desrespeitam os sujeitos de suas matérias. Por exemplo, a vida de uma comunidade isolada, que vive em condições estranhas e mesmo exóticas para o morador de um centro urbano pode se enquadrar em uma dessas situações as quais ele tem o direito de saber. Afinal, retrata um modo de vida diferente do seu: é um direito a conhecer a pluralidade de culturas existentes no mundo, o que pode, inclusive, contribuir para o ato de repensar o seu próprio modo de vida. Mas a comunidade retratada pode não compartilhar essa opinião, ou mesmo não ter clareza sobre o que será feito de sua imagem e quais as conseqüências de tê-la divulgada.

Segundo Bucci (2000, p.37), o principal entrave para a discussão de uma conduta ética no jornalismo são os próprios jornalistas. O assunto da ética é muitas vezes evitado pela dificuldade de suas conclusões serem aplicadas no dia-a-dia de uma redação. Todos concordam que as informações devem ser checadas antes da publicação, que as pessoas têm direito à privacidade, que ninguém é culpado antes de um julgamento final. Mas, conforme 
pontua o autor, na competição diária pela notícia exclusiva, fotógrafos, repórteres e editores atropelam esses princípios.

No fotojornalismo, portanto, a questão ética na relação do fotógrafo com o sujeito fotografado passa muitas vezes por uma conduta pessoal. Independente de o fotógrafo estar atrelado às pressões da imprensa ou estar livre para realizar um trabalho autoral, estabelecer ou não uma relação de sinceridade para com a pessoa fotografada é, quase sempre, uma opção pessoal. Imagens como as produzidas por Sebastião Salgado na Serra Pelada, por Milton Guran entre os Arara, Yanomami e Xavante ou por Walter Firmo, apenas citando alguns exemplos, são fotografias em que fica claro o envolvimento do fotógrafo com o tema fotografado, e principalmente, o consentimento deste para a obtenção da imagem.

Sobre essa questão, o fotógrafo Walter Firmo vê a câmera fotográfica como

uma abominável caixinha (...) na medida em que ela invade você, o arremessa, chega e o abre, abre as pessoas. Ela tanto pode fazer um regime cair quanto uma pessoa - que é muito mais, é um mundo - se mostrar. (...). Como sei que estou atrás da câmera, fotografando as pessoas, noto que elas às vezes não gostam de ser fotografadas. Quando levantam a mão em sinal de que não querem a foto, envergonho-me, procuro respeitá-las.

A necessidade do diálogo e da aproximação com o tema a ser fotografado é pontuada por vários fotógrafos (Ivan Lima, Sebastião Salgado, Rogério Reis, André Boccato). Mas muitos colocam que essa aproximação requer um tempo e uma profundidade que a dinâmica do fotojornalismo não oferece. O veículo no qual o fotógrafo trabalha, seja jornal, revista ou agência de notícias, é muitas vezes visto como uma camisa de força que poda a criatividade e as possibilidades do profissional (Guran, 1989; Reis, 1989).

Uma das maiores queixas dos fotógrafos em relação ao fotojornalismo é a fragmentação do trabalho no processo de composição de uma matéria, isto é, o fotógrafo fotografa, o repórter escreve, e muitas vezes quem escolhe a imagem não é nem um nem 
outro: quando muito um editor de fotografia, mas que nem sempre é capacitado para essa função ou dialoga com o fotógrafo.

Sobre o distanciamento entre o fotógrafo e seu tema, Rogério Reis comenta:

Muitas vezes você entra na casa do entrevistado, fotografa a casa, dá bom dia e até logo, pouco conversa. De um tempo pra cá, isso foi me sufocando. Ultimamente tenho, ás vezes, interferido na conversa entre o repórter e o entrevistado. Venho percebendo que consigo, interferindo, cativar um pouco da intimidade da pessoa.

O fotógrafo Sebastião Salgado, ilustra a perspectiva de um novo fotojornalismo, no qual o fotógrafo não rouba imagens, mas mergulha dentro de uma realidade. Assim, é capaz de fazer uma interpretação sincera e profunda acerca da pessoa ou situação fotografada.

No entanto, a questão do tempo é crucial no fotojornalismo. É comum que o fotógrafo saia a campo com 6 a 8 pautas para cobrir em um turno de trabalho. Nas conversas que tive com fotógrafos de jornais de Porto Alegre, pude observar a pressão na qual são submetidos. Muitas vezes a fotografia é "armada", já que o fotógrafo não pode esperar pelo momento exato de se produzir a imagem. Como afirma Guran (1989), o trabalho do fotojornalista é subordinado às circunstâncias.

O fotojornalismo, assim, trabalha muitas vezes com a noção de imagem do anônimo, em que as pessoas aparecem na foto para ilustrar uma situação: não se está, necessariamente falando a respeito delas. Quando se faz uma fotografia na rua, por exemplo, mostrando um incêndio, um acidente ou qualquer reunião de pessoas em torno de um fato - que dá notícia -, dificilmente o fotógrafo pede o consentimento das pessoas envolvidas. Ocorre quase que um acordo tácito: quem estiver ali naquele momento está sujeito a ter sua imagem captada e publicada.

\section{Confronto de olhares: fotojornalismo, ética e trabalho de campo}

No período de minha pesquisa destinado ao trabalho de campo, entrevistando alguns moradores do distrito de Barra do Ouro - RS, houve um entrevistado, em especial, a quem fiz duas pontuais visitas. Apresento-o aqui, neste momento de minha monografia, por 
acreditar que o desenrolar da história relatada ilustra bem os meandros do dialogo que procuro construir, teórica e conceitualmente tanto quanto metodologicamente, entre a prática jornalística e a pratica antropológica com recursos audiovisuais no que se refere as formas de se trabalhar com fotografia e com o sujeito fotografado.

João Demoliner, conhecido por Joanin, é o mais antigo morador ainda vivo da Barra do Ouro. Com 97 anos, ele pouco escuta, pouco fala. Em uma conversa não muito longa, mediada por sua nora para que eu me fizesse entender, Joanin falou pouco sobre o tempo antigo na Barra e sua vida de colono no Rio do Ouro. Mais do que a conversa, foi sua figura que me chamou atenção. Encontrei-o comendo laranjas na varanda, usando um chapéu de palha e mascando pequenos retalhos de fumo. Era um retrato perfeito. Com pouco tempo de conversa, pedi para fotografá-lo: ele indagou o porquê mas

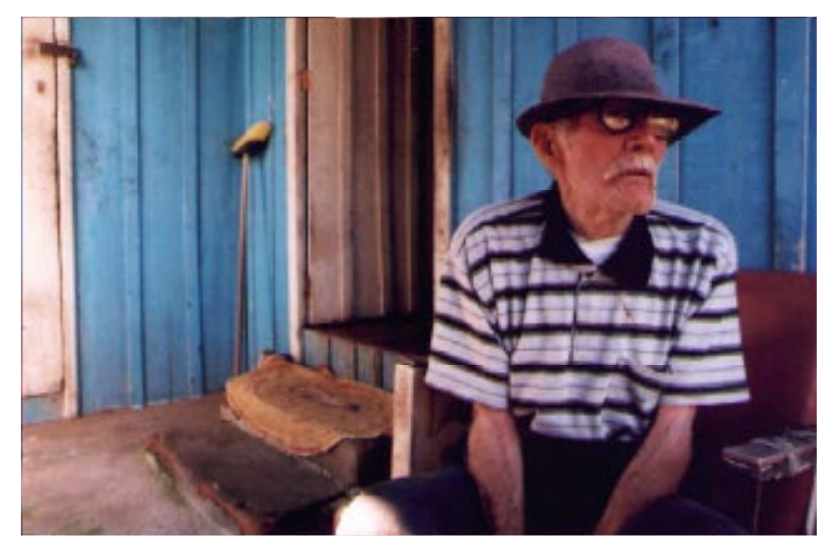
consentiu. Algumas semanas depois, voltei à Barra do Ouro. Era um final de semana chuvoso, eu havia marcado uma entrevista com Pedro Witcoski, outro morador que me havia sido indicado para a realização deste trabalho, pela manhã e tinha, portanto, uma limitação de horário. Pedro era amigo de infância de Joanin e também um dos moradores mais antigos da Barra do Ouro. Decidi levar as fotos para Joanin perto do horário marcado para a entrevista, quando supostamente estava com pressa. Ele apareceu na janela, conversamos rapidamente embaixo da chuva, mostrei-lhe as fotos e vi sua expressão de contentamento. Mas despedi-me sem que, com as imagens em mãos, ouvisse dele o riso, a fala, o silêncio. Não procurei mais Joanin.

Os motivos que me levaram a esse distanciamento foram vários, mas especialmente o medo de ver o resultado de minha presença na vida das pessoas que constituem o meu campo de trabalho. Eu estava, de certa forma, consumindo uma imagem que era para mim interessante e singular, assim como os fotógrafos e antropólogos mencionados anteriormente, que buscavam no exótico material para suas pesquisas e acervos. 
A partir deste relato penso que é possível fazer uma analogia desse episódio com um modo de agir comum entre os jornalistas e fotógrafos, que trabalham com a captação de estórias e imagens sem se preocupar com a devolução desse material. Porque retornar a campo significa, primeiramente, admitir que não se tratam apenas de imagens e estórias passíveis de serem lidas ou consumidas, mas de pessoas e suas vidas. Em segundo lugar, significa sujeitar o próprio trabalho à crítica daquele que tem sua imagem e sua vida traduzidas pelo jornalista. É dessas pessoas que vem a resposta mais valiosa - e mais difícil ao trabalho de um jornalista, e não do editor ou de uma anônima pesquisa de opinião.

\section{Jornalistas fazem etnografia? compartilhando olhares}

\section{Uma fotojornalista "em campo": cruzando fronteiras}

A imagem fotográfica foi desde o início a motivação desta monografia. Na verdade, foi o desejo de unir três aspectos da minha vida: meu trabalho como fotógrafa, a relação que vinha se estreitando com a área da antropologia e os estudos da memória, e um trabalho que desenvolvo há alguns $\operatorname{anos}^{1}$ no distrito de Barra do Ouro - Maquiné. O desenvolvimento deste trabalho de conclusão foi em si a experimentação de uma junção equilibrada desses aspectos, o que envolvia uma experiência cotidiana da prática profissional, estudos em um terreno ainda pouco explorado, e o trabalho de campo, modificador por excelência dos rumos de qualquer pesquisa.

O trabalho de campo encontra-se na base de qualquer pesquisa antropológica. É o momento em que o pesquisador efetivamente entra no campo a ser estudado, mergulha em uma realidade que não é mais a sua, mas uma realidade nova, diferente, estranha, exótica até. O diário de campo e a descrição etnográfica são importantes instrumentos através dos quais o antropólogo registra os acontecimentos vividos em campo: é uma forma de resgatar, na lembrança, a interação vivida com o grupo/indivíduo pesquisado. Ampliando a

\footnotetext{
1 O Programa Colégio Amarelo se constitui na etapa atual de um trabalho desenvolvido desde 1997 no distrito de Barra do Ouro e arredores, acerca do patrimônio histórico, cultural e arquitetônico dessa comunidade. Identificando- se o prédio da antiga Escola Estadual Hilário Ribeiro, conhecido como Colégio Amarelo, como um importante exemplar do patrimônio para a comunidade, o trabalho vem atuando no sentido da revitalização (na realização de atividades culturais no prédio, tais como oficinas, projeção de filmes, etc.) e restauração (na constituição de um caderno inventário do prédio, na interlocução com o poder público gestor do espaço, na proposta de um projeto participativo de restauração) desse espaço, e em sua consolidação como um espaço coletivo e abrigo de iniciativas comunitárias. O Programa é desenvolvido pela ONG Anama e atualmente conta com o apoio da Prorext/UFRGS e com dois bolsistas de extensão na área de arquitetura.
} 
noção de trabalho de campo, é possível pensar que jornalistas também vão a campo e elaboram seus diários: embora no geral possam ser mais sucintos e informativos, o campo também constitui uma parte fundamental do fazer jornalístico.

Minha entrada em campo na Barra do Ouro é bem anterior a essa pesquisa. Desde 1997, quando conheci Maquiné, essa região vem se constituindo no meu principal destino nos finais-de-semana. No ano de 2000, passei a integrar de forma efetiva a ONG Anama Ação Nascente Maquiné ${ }^{2}$ em um dos projetos desenvolvidos pela ONG, centrado na área de patrimônio cultural e na revitalização e restauração de um prédio que já havia sido a sede de uma antiga escola local. Assim, eu já era conhecida pela comunidade como uma das "gurias que trabalham no colégio"3. Esse reconhecimento facilitou minha entrada em campo: mesmo que o trabalho da Anama seja na comunidade uma questão polêmica e que divide opiniões, eu era ali um rosto conhecido, e relacionado aos trabalhos de pesquisa.

No caso específico desta monografia, o trabalho com memória na Barra do Ouro foi motivado por uma vontade de conhecer e ser conhecida mais de perto, e fora do grupo, por essa comunidade. A idéia de trabalhar com imagem e memória foi crescendo a partir de um trabalho de pesquisa realizado nos anos 2001/2002, no município de São José dos Ausentes, denominado "O uso do retrato para resgate da memória oral". Nessa pesquisa, registrávamos as estórias de alguns moradores tomando como ponto de partida seus álbuns ou caixas de fotografias.

$\mathrm{O}$ confronto entre minhas experiências anteriores e as atuais propostas para esse trabalho foram matizadas por minha entrada em campo para a realização desta monografia. Em um dos diários de campo, escrevi:

\footnotetext{
2 A Anama foi criada em 1996 por um grupo de estudantes e pesquisadores. Desde então, vem desenvolvendo trabalhos em diferentes áreas direcionados à busca de um desenvolvimento saudável na região de Maquiné, aliando a preservação ambiental à alternativas sócio-econômicas compatíveis com a realidade local. Em linhas gerais, são algumas das ações/projetos: Rede de Educação Ambiental; Avaliação da Qualidade das Águas; Patrimônio Cultural, Histórico e Arquitetônico; Mutirão de Limpeza do Rio; Encontro de Pesquisadores do Vale do Rio Maquiné; Implantação de Sistemas Agroflorestais; Samambaia-preta: avaliação etno-biológica e sócio-econômica;

3 O trabalho de revitalização na antiga escola reúne muitas das tensões existentes na Barra do Ouro. Construído em forma de mutirão em 1920, o prédio é um orgulho local, mas também é visto como uma coisa velha, sem utilidade, e que deve ser "tombada", derrubada. Hoje o prédio é utilizado por grupos de mulheres, no desenvolvimento de trabalhos comunitários, como o Clube de Mães e a Farmácia Caseira Comunitária, já tendo também sediado as aulas do MOVA. A utilização do prédio e nossa inserção em campo são questões polêmicas, dividindo opiniões na Barra do Ouro, e de certa forma, aqueles que apóiam ou não o nosso trabalho.
} 
O campo é aquela parte do trabalho que balança nossas certezas teóricas: a estrutura de uma pesquisa pode ser perfeita até que se vá a campo. Situa-se aí o meu caso: com uma idéia segura e facilmente solucionável, fui a campo, e voltei com ela dentro da pasta, no meio dos livros, zíper fechado. Por um lado, pela própria idéia que se modifica e ganha novos contornos; por outro, pelo desafio de escrever a experiência de campo, aquilo que se vive, revive e compartilha numa entrevista aquecida pelo calor do fogão à lenha, aquilo que se sente ao caminhar sozinha na estrada, ou o que a chegada no lugar nos propõe.

Dessa forma, o trabalho foi se modificando em seu próprio percurso. As mudanças nos rumos desse trabalho se deram especialmente no que tocava ao lugar da imagem fotográfica na pesquisa. Minha entrada em campo foi o que transformou uma idéia acerca de um grupo e da pesquisa que eu pretendia realizar em um material vivo de observações e experiências vividas. Num primeiro momento, com a intenção de realizar um trabalho que investigasse a relação entre fotografia e memória, fui em busca de uma imagem que fosse significativa da história da comunidade da Barra do Ouro.

Assim, a primeira entrevista foi motivada por uma fotografia em especial, da qual eu já sabia a existência, que ilustrava as ruínas da igreja local um dia após o incêndio que a destruiu parcialmente, na década de 60. Encontrei não apenas a imagem, mas narradores que me puseram em contato com outras estórias do lugar, e que foram aos poucos compartilhando comigo as estórias de suas vidas. O interesse que a princípio se restringia a apenas uma fotografia, foi sendo ampliado na medida em que percebia a existência de outras imagens, mais sutis e sem a característica material que envolve a fotografia. Nas conversas com os entrevistados, cada lembrança era uma imagem mental livre e poética, uma imagem literária e que para mim, enquanto fotógrafa e ouvinte, correspondia a uma imagem fotográfica. Surgiu daí a vontade de fotografar as imagens que eram suscitadas pela memória dos entrevistados.

Percorrendo os caminhos da linha do Rio do Ouro, uma das linhas mais habitadas no tempo antigo, e bastante citada nas narrativas de todos os entrevistados, fotografei 
traços do passado e modificações do presente: antigas propriedades, fornos desativados, igrejas abandonadas, cultivos de milho, feijão e uva, plantações de eucalipto, o mato que substituiu a roça. A obtenção dessas imagens, tinha para mim múltiplos sentidos:

- estabelecer uma relação de troca com os entrevistados, estreitando a relação pesquisador - narrador;

- refazer os percursos da memória dos entrevistados ressignificando antigas imagens da memória na paisagem de hoje, e sob um outro olhar, uma outra interpretação;

- observar que aspectos as imagens do presente evocavam na narrativa dos entrevistados;

- sujeitar a minha interpretação e a validade de meu trabalho enquanto fotógrafa às apreciações e possíveis críticas dos entrevistados;

- experimentar uma prática pouco comum no jornalismo: a devolução da imagem do Outro;

Esses objetivos foram pensados com base na utilização da imagem no campo das Ciências Sociais, onde ela pode funcionar como um simples registro, evidenciando o olhar e as considerações do pesquisador sobre os grupos e fenômenos estudados e sobre sua própria pesquisa etnográfica ${ }^{4}$, ou como um recurso metodológico, contribuindo para um melhor entendimento do campo, pelo pesquisador e pelos grupos pesquisados. A atribuição de significados às imagens de si e dos outros, por parte dos grupos pesquisados, é um processo importante a ser considerado em um estudo etnográfico. Assim, o que importa para as Ciências Sociais não é a foto em si, mas a reflexão que pode ser desenvolvida a partir dela (Guran, 1998). Dentro dessa abordagem antropológica, o retorno das imagens às pessoas fotografadas é tido como uma forma eficaz de estreitar o laço pesquisador pesquisado, imbuindo-as de propriedade para discutir a pertinência das representações de si. Assim, a fotografia pode ser um instrumento de observação capaz de incluir o próprio observador e expô-lo à apreciação dos outros. (Maresca, 1998).

\footnotetext{
廿 O termo "etnografia" é de forma geral entendido como o estudo descritivo de diferentes grupos humanos, entretanto, é um termo que nomeia uma tradição de pesquisa na antropologia, ainda em discussão. Clifford Geertz (2002), ao afirmar que não há ainda uma clareza sobre o que seja a etnografia, coloca que "talvez a etnografia seja uma espécie de escrita, um colocar as coisas no papel, é algo que tem ocorrido, vez por outra, aos que se empenham em produzi-la, consumi-la, ou ambas".
} 
A escolha entre produzir imagens coloridas ou preto e branco foi difícil. Como fotógrafa, aprecio o preto e branco por sua evidente distinção da realidade e pela gama de significações que ele é capaz de suscitar; como pesquisadora em campo, entendia que as imagens tinham como objetivo mostrar o presente, como um tempo dinâmico e em constante transformação, e portanto, colorido. A memória é feita de imagens coloridas, nós não pensamos nem lembramos em preto e branco, porque nossa lembrança, apesar de referir o passado, é sempre viva e presente. Deixei de lado as preocupações estéticas e busquei fazer imagens "tradicionais", ou amadoras, sem ângulos e enquadramentos inovadores e de difícil leitura. Mesmo assim, minha tentativa de "tradicional" estava imbuída de uma tradição fotojornalística, que valoriza determinados ângulos, enquadramentos e condições de luz em detrimento de outras, e que pode diferir em muito das imagens que os entrevistados estavam acostumados a olhar.

Voltei a campo com essas fotografias em mãos, ciente da possibilidade de que as mudanças nos atos de rememorar e contar dos entrevistados não se fizessem tão visíveis, de que o interesse do entrevistado pelas imagens fosse breve e sucinto, ou de que minhas interpretações não dissessem muito para suas imagens mentais. De qualquer forma, ia com a certeza de experimentar uma nova maneira de conduzir uma entrevista, tanto no que tange à relação pesquisador - narrador, quanto na inserção de um elemento imagético novo, representando um pedacinho do presente impresso no papel, em meio a uma conversa onde se evocam, principalmente, imagens do passado.

\section{Ouvindo os narradores: 0 momento da entrevista}

Os entrevistados escolhidos como objeto e tema desta pesquisa eram todos pessoas de idade superior a 78 anos. A primeira entrevistada, Geni Soares Carpinski, era sogra de uma importante informante e parceira no trabalho que já desenvolvíamos na Barra do Ouro pela ONG. Procurei Dona Geni em busca da fotografia do incêndio na igreja. Foi ela a me indicar os nomes dos outros informantes, Pedro Witcoski e João Demoliner por serem os mais antigos moradores da Barra do Ouro, e certamente por fazerem parte de uma rede de relações sociais a qual todos pertenciam. Arlindo Adamatti, meu quarto e último informante, parecia estar mais distante dessa rede, por uma condição distinta dos demais: 
era fotógrafo, e não colono, e diferentemente dos demais, havia se estabelecido na sede de Maquiné, onde vive até hoje.

Fui a campo procurando pelos "mais velhos" da Barra do Ouro, com a hipótese de que seriam eles os mais capacitados a reconstituírem uma visão completa do passado. Passei a repensar essa escolha quando vi que alguns dos entrevistados já tinham perdido a vontade ou as condições para ouvir, falar, ver e contar estórias. Por vezes os relatos dos familiares, com idades entre 50 e 70 anos era mais vivo e detalhado; de qualquer maneira, a relação com esses narradores já havia se estabelecido, e suas narrativas passaram a chamar minha atenção justamente por essa peculiaridade: como pessoas de tanta idade, que já viveram tempos quase iguais de infância, idade adulta e velhice, elaboram suas estórias de vida? Para Myriam Lins de Barros (1987), em um estudo que aborda a relação entre as gerações na família brasileira, especialmente do ponto de vista dos avós, a pessoa realiza revisões sucessivas durante a vida e a revisão no momento da velhice acontece muito em função da proximidade da morte. Segundo a autora, a presença da morte traz por si só a força da revisão de vida e a familiaridade com a idéia de fim (1987, p. 94).

Também a idéia de uma visão "completa" foi se desfazendo no desenrolar das entrevistas: na maior parte das vezes, o passado aparecia de maneira fragmentada e num primeiro momento desconexa, até que as peças fossem se encaixando. A objetividade com que entrei em campo, ansiosa por saber das estórias dos informantes, foi dando lugar a um movimento mais flexível, entremeado de espera, repouso e ação. A memória impunha seu ritmo e tecia, ela mesma, uma narrativa do meu "estar em campo".

Nas primeiras entrevistas ainda buscava nos relatos dos narradores algumas pistas sobre o episódio do incêndio da igreja. De modo geral, pedia que os entrevistados me falassem do passado da Barra do Ouro, dos hábitos e costumes do tempo antigo ali. Alguns falaram da vida de antigamente, outros falaram de suas próprias vidas. Cada informante tinha uma peculiaridade que me levava a entrevistá-lo, e era a partir do pouco que sabia sobre suas vidas que a entrevista se desenrolava. Com Seu Arlindo Adamatti, por exemplo, o tema era essencialmente a fotografia: me interessava muito saber como era ser um fotógrafo em meados do século na Barra do Ouro.

Para Paul Thompson (1992), no livro “A voz do passado”, a entrevista não pode ser completamente livre. Para que se estabeleça uma relação de entrevista, sem que esta seja 
necessariamente um modelo rígido de perguntas e respostas, é preciso que o pesquisador deixe claro o contexto e o objetivo da entrevista e da pesquisa, fazendo ao menos uma pergunta inicial. Uma total falta de direcionamento na entrevista pode fazer com que o entrevistado fique confuso sobre o que o entrevistador deseja saber, resultando em relatos curtos e concisos. Muitas vezes os entrevistadores, no intuito de deixar o entrevistado livre para expressar aquilo que quer, acabam esquecendo que a entrevista é, antes de tudo, uma ocasião de diálogo, e que o entrevistado muitas vezes dá o gancho para que sejam feitas as perguntas que querem responder. $\mathrm{O}$ envolvimento do ouvinte/pesquisador na fala do narrador/pesquisado é fundamental: parafraseando Benjamin, quanto mais o ouvinte se esquece de si mesmo, mais profundamente se grava nele o que é ouvido (1994, p.205).

Os momentos de silêncio se faziam presentes em todas as entrevistas. Nessa hora, me deparava com o estranhamento e um certo constrangimento de estar ali, remexendo o baú de lembranças dos entrevistados, pedindo-lhes que me contassem suas vidas. É um momento em que o entrevistado pode estar repensando aquilo que acabou de dizer, refletindo sobre sua trajetória e condição atual de vida, ou ainda, questionando silenciosamente o entrevistador e a situação de entrevista na qual se encontra. Os momentos de silêncio são os momentos de repouso, reflexão e reconhecimento: a quebra brusca do silêncio com uma pergunta pode ser uma necessidade do pesquisador de sair dessa situação incômoda. O extremo oposto seria o pesquisador cair numa passividade na relação de entrevista, que pode ser interpretada como desinteresse. O reconhecimento e a compreensão do processo da entrevista em sua totalidade, com os encontros e desencontros entre pesquisador e informante, é o que pode trazer o equilíbrio na condução desta. Em alguns momentos não suportei o silêncio, e perguntei, perguntei, perguntei. Em outros, silenciava-me por um tempo demasiado diante da carga emocional contida em um relato, mesmo percebendo que o entrevistado gostaria de continuar a conversa e que aquele momento poderia revelar coisas surpreendentes sobre suas vidas. Percebia que o silêncio funcionava como um limite também de minha parte, como receptora das estórias e emoções daquelas pessoas.

Ecléa Bosi, no livro "Lembrança de velhos", comenta que a conversa evocativa do velho é sempre uma experiência profunda, um momento repassado de nostalgia, revolta, resignação pelo desfiguramento das paisagens caras e pelo desaparecimento dos entes 
queridos (1994, p.82). Uma das informantes, Dona Geni, em todas as nossas conversas me falava da tristeza causada pela morte recente de uma amiga, que nos últimos anos passava as noites com ela. Frente a esse sentimento, eu não dispunha de nenhuma pergunta ou resposta, apenas da escuta. Via o sofrimento que essa perda ainda lhe causava, e percebia que , ao trabalhar com memória - de acontecimentos recentes ou distantes - não era depositária apenas do passado dessas pessoas, mas de todos os sentimentos que ainda afloram desse tempo, e de suas repercussões no momento presente.

Na entrevista com um dos informantes, Seu Arlindo, sua filha se mostrou contrária à continuidade da entrevista. Fiquei confusa com a tutela que era reservada à Seu Arlindo, já que ele se mostrava feliz frente à situação de entrevista e à possibilidade de falar do passado. Afinal, quem era o meu narrador, a vontade de quem deveria respeitar? De qualquer forma, senti que estava invadindo um terreno familiar ao qual não era chamada. Estava vivendo, em campo, aquilo que Roberto DaMatta (1978) chama anthropological blues, no momento em que afloravam elementos que já se insinuavam na prática etnológica, mas que não estavam sendo esperados. Os sentimentos e as emoções que surgem da relação pesquisador/entrevistado são, para o autor, o lado mais difícil de ser apanhado da situação antropológica, justamente porque se constituem no aspecto mais humano dessa rotina $(1978$, p. 35)

Nesse sentido, quando pedimos a alguém que nos conte sua vida, que compartilhe conosco suas lembranças, estamos sempre lhe pedindo muito. A conversa evocativa da memória é sempre uma experiência profunda, uma situação limite, de onde podem vir à tona o riso e o choro, o afeto e a raiva, sentimentos sempre prontos a emergir em qualquer relacionamento humano. Estamos falando de nossa vida e portanto, revivendo-a: é quase fatal nos depararmos com aspectos que preferíamos deixar de lado.

Teresa Pires Caldeira (1980), em artigo no qual discute o lado não respeitável do trabalho de campo, faz uma incursão pelo universo que é a situação de entrevista e a relação entre pesquisador e pesquisado. Segundo ela, a relação que se estabelece em campo entre o pesquisador e seu informante é uma relação de poder, onde um requer um depoimento e o outro se vê na contingência de responder. Para a autora, essa relação decorre de uma associação histórica entre poder e saber científico. No entanto, como ela própria faz questão de ressaltar, essa situação é vivida ambiguamente, tanto pelo 
pesquisador quanto pelo entrevistado, pois a situação de poder do entrevistador não dá conta de tudo o que ocorre na relação: a partir de um momento, é o entrevistado que imprime seu tom na conversa, é ele "quem sabe". Mesmo assim, a reação dos entrevistados sempre causa surpresa ao pesquisador, por mais que se insinuem durante todo o trabalho de campo.

\section{Tirando fotos: considerações sobre imagens roubadas e imagens restituídas}

Quem observar os movimentos de um fotógrafo munido de aparelho (...) estará a observar um movimento de caça. $O$ antiquíssimo gesto do caçador paleolítico que persegue a caça na tundra, com a diferença de que o fotógrafo não se movimenta na pradaria aberta, mas na floresta densa da cultura.

$$
\text { Vilém Flusser,1998, p.49 }
$$

A figura do caçador de Flusser (1998) explica-se: para o fotógrafo, a imagem é sempre um trunfo, uma realização pessoal. É a forma na qual seu olhar sobre o mundo é materializado, tornando-se concreto e palpável. A caça, no entanto, não pode reclamar o seu ferimento; mas a pessoa fotografada pode querer de volta a sua imagem roubada.

A questão entre fotógrafos e fotografados é antiga. Mesmo com as mudanças que a fotografia e o fazer fotográfico sofreram ao longo do tempo, mesmo com a ambigüidade dos sentimentos de medo e admiração quando de seu surgimento, a fotografia sempre esteve acompanhada de um certo constrangimento. Um receio por parte dos fotografados, justificado de diferentes formas, de acordo com o desenvolvimento da técnica e o momento histórico no qual a fotografia estava inserida.

O avanço da tecnologia fotográfica foi modificando a relação do fotógrafo com o tema fotografado. A redução do tempo de exposição, o desenvolvimento de câmeras menores e de lentes capazes de aproximar o assunto foram algumas das inovações que fizeram com que a fotografia se expandisse pelo mundo e ao mesmo tempo se afastasse dos 
assuntos fotografados. Foi uma mudança técnica, mas que delineou um novo quadro na fotografia contemporânea. Tornou-se possível fotografar sem ser visto e manter uma posição de distanciamento do assunto. $\mathrm{O}$ ato de fotografar, que presume uma situação envolvendo duas partes, um diálogo e uma negociação, transformou-se em uma via de mão única. Por isso a idéia de foto roubada.

Quando entramos em contato com sociedades tradicionais, somos a cada momento surpreendidos com as reações de estranhamento diante da imagem fotográfica. Mas será possível nos colocarmos no lugar desse Outro - que teve pouco ou nenhum contato com a imagem fotográfica - e voltarmos nosso olhar para o tempo em que a fotografia não existia? Se conseguirmos sentir ainda que sutilmente esse estranhamento, nosso gesto de fotografar não será mais o mesmo.

A surpresa com que Dona Geni recebeu as fotos que havia feito dela, sua estranheza diante das imagens e sua sincera tentativa de compreendê-las foram alguns momentos em que tive esse contato. Longe de ser um artefato banalizado, para algumas pessoas a fotografia pode ser, ainda hoje, algo muito especial, algo que as traduza. Mesmo para aqueles que tenham no ato de fotografar e ser fotografado algo corriqueiro, a imagem de si sempre chama atenção. Ela é vista e revista; é a imagem de nós mesmos que só o Outro pode captar.

$\mathrm{O}$ receio e constrangimento que mencionei anteriormente me acompanhou durante toda a pesquisa. Em contrapartida à minha experiência cotidiana de trabalho ${ }^{5}$, onde sou solicitada a fotografar continuamente situações envolvendo pessoas, nessa monografia me propunha a refletir sobre o consumo excessivo de imagens, do qual eu mesma era uma representante. Estava, dessa forma, relativizando e estranhando uma ação que para mim era quase natural: tirar fotografias. Para Roberto DaMatta (1978), estava transformando o que me era familiar em exótico, podendo estranhar os aspectos e as regras sociais que envolvem a obtenção de uma imagem. Ou ainda, segundo Gilberto Velho (1997), estava observando aquilo que era familiar, mas não completamente conhecido.

Por isso, e especialmente depois do episódio com um dos entrevistados, relatado no capítulo anterior, a câmera fotográfica levou algum tempo até voltar à cena nessa pesquisa. 
Na primeira entrevista com cada um dos entrevistados, não levei a câmera fotográfica. Foi na segunda ou terceira visita que pedi para fotografá-los, e todos concordaram, embora não entendessem o motivo. Quando me perguntavam por que eu iria querer ter fotos suas, eu também me perguntava. Expliquei que lhes devolveria as fotos, para que se vissem em fotografias e tivessem recordações desse momento .

Ao contrário do que faço cotidianamente, onde me movimento com rapidez e me aproximo às vezes excessivamente da pessoa a ser fotografada na busca de uma imagem que possa traduzir o evento, quando fotografei os informantes, optei por ângulos e enquadramentos que não exigissem meu deslocamento. Se em meu trabalho cotidiano a relação com a pessoa fotografada se encerra no momento da obtenção da foto, já que na maior parte das vezes não torno a vê-la, na pesquisa com os narradores esse era apenas um dos pontos de nosso diálogo. Tinha receio de que, ao fotografá-los, meu olhar se distanciasse do deles e de suas narrativas, principalmente porque queria fotografá-los em em ação: falando, contando as estórias, olhando as fotografias. Minha entrada como fotógrafa em uma situação onde até então era apenas ouvinte causaria um estranhamento nos informantes. Não queria que eles se sentissem invadidos, "captados". Tinha medo de roubar as imagens desses narradores. Esse medo partia do pressuposto de que fotografar implica em um distanciamento do tema fotografado, o que não é necessariamente verdadeiro, mas até o momento era o que pontuava meu trabalho como fotógrafa, mesmo que eu só tenha percebido isso a partir desse trabalho. Todo esse receio se fez menor do que a resposta concreta dessas pessoas frente ao ato de fotografá-las: os narradores pareciam ter mais naturalidade do que eu frente a situação de estarem sendo fotografados.

\section{A escuta e a fotografia: voz e imagem dos narradores}

A opção pela utilização dos nomes reais dos narradores é fundada, antes de tudo, no consentimento destes. A idéia de utilizar nomes fictícios me pareceu descabida, na medida em que eu buscava retratar experiências de vida que eram singulares daquelas pessoas, e principalmente fazer emergir sua voz num contexto onde ela é pouco escutada. Minha

5 Durante o período de novembro de 2002 até o presente momento, trabalhei como estagiária de fotografia na Câmara Municipal de Porto Alegre, o que me proporcionou um contato direto com o dia-a-dia no fotojornalismo e 
preocupação consistia em justamente escapar da proposta de utilização do anonimato como uma forma de "proteger" tanto o sujeito pesquisado como o próprio pesquisador, muito comum no jornalismo. A voz e a imagem dessas pessoas não são anônimas, têm dono. É assim que Dona Geni, Seu Pedro, Seu Arlindo e Joanin, como afetivamente eu passei a chamá-los, são apresentados aqui: como o resultado de um encontro etnográfico.

\section{Geni Soares Carpinski}

As mulher véia em pé faziam assim, pegava o vestido assim puxava e mijava. Em pé mesmo. Só puxava o vestido, pronto, era um vestidão largão, né.. É, a vida da gente mudou muito. Não é mais a vida aquela que a gente tinha.

Chamei pelo nome de Dona Geni e esperei uns instantes. Ela respondeu que já ia, e quando me viu pela portinhola trancou o passo e olhou ressabiada. Ao vê-la, fiquei feliz reparando as marcas de sua idade no rosto e corpo. Tinha muita curiosidade em conhecê-la e um certo receio de que fosse mais jovem do que eu imaginava. Ela se aproximou e eu me apresentei

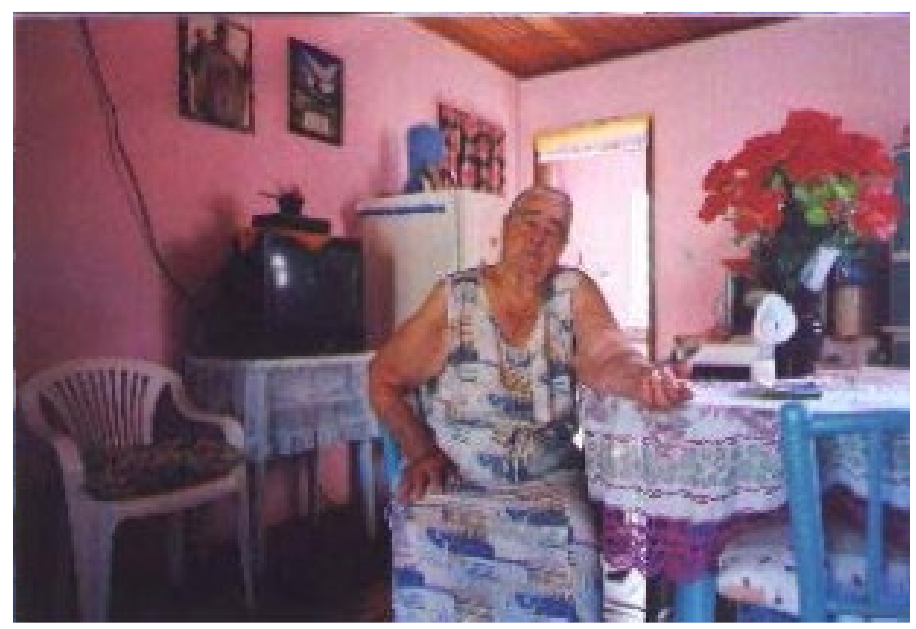
pelo nome, a resposta foi "não te conheço". Mesmo assim ela abriu a porta e então expliquei o motivo de minha visita: uma amiga havia dito que ela tinha uma foto antiga do incêndio da igreja, e que eu gostaria de vê-la. Dona Geni se virou dizendo para eu entrar e ficou tonta, quase caindo sobre as cadeiras. Eu a amparei e a senti frágil, enquanto ela reclamava da tontura e dessas coisas da idade. Caminhamos até a porta da cozinha, de onde 
ela pegou o retrato, emoldurado e provavelmente pendurado na parede. Enquanto tirava o pó do retrato com a mão, comentou que outras pessoas já haviam lhe pedido para ver a fotografia. Esse primeiro dia foi para mim uma entrevista, embora não tivesse comigo máquina fotográfica ou gravador. À medida em que minhas visitas se tornavam mais frequientes, a entrevista se transformava em conversa, ao redor da mesa, e aquilo que Dona Geni me contava não era apenas sobre o tempo antigo, mas sobre o tempo de sua vida.

Filha e neta de "brasileiros", Dona Geni nasceu nas proximidades da Barra do Ouro. Ali viveu até a mocidade, quando casou com um descendente de poloneses e mudou-se com ele para o Rio do Ouro.

Já fui morar na minha casa, não ia morar com a mãe dele. Ele tinha outras irmã, né, outras irmã. Fui morar sempre sozinha, me casei e já fui pra minha casa. Não morei em casa de ninguém.

Lá, viveram na colônia e tiveram quatro filhos. Do tempo em que trabalhavam na roça, Dona Geni conta que plantavam arroz, trigo, milho, feijão, uva, além das "miudezas pra casa", como batata e aipim. A vida na colônia, ou "no fundo", é lembrada com orgulho. A imagem de uma mulher trabalhadora e conhecedora das coisas da roça era sempre passada durante as entrevistas. Em dado momento, ela contrasta sua sabedoria com o jeito “bobo” das irmãs, que não viviam na colônia:

Até minhas irmã quando iam lá elas iam pro fundo e entraram no porão, primeira vez, tinha salame novo, salame mais véio e bem véio, né, então elas diziam que aquele véio lá elas não queriam, que aquele já tava podre, tava embolorado, né, a pele da lingüiça quando o salame é bom, fica velho, seca, cria aquele branco, né, e elas dizia que aquele elas não queria porque tava podre, ó lá não enxerga que ta tudo branco? Comiam bastante salame daquele outro mais fresquinho que aparecia as tripa ainda, né. Depois entravam, e se riiiam quase morriam, eu nem via porque minha casa tinha porão, embaixo dava outra casa e nós morava em cima. Aquele ebaixo então nós temo o porão que lá nós tinha as tina de vinho, botava salame, botava tudo as coisa lá, botava a banha, tudo lá no porão, né. E elas entravam lá e iam comer o salame. 
Quando eu fazia café pra elas e botava aquele salame que era que elas diziam que era podre, que não prestava, elas dizia uie como nós somo boba, diz ela assim, repara que aquilo ficava vermeinho, verde que nem a carne viva assim, um salame especial mesmo que naquele tempo a gente fazia, ficava bem vermeinho assim cor da carne mesmo, e nós fomos comer aquele verde lá, diz elas, e aquele lá sequinho, bom...eu disse pois é, vocês são boba, né.

Lembrando a saída do Rio do Ouro quando os filhos ainda eram pequenos, ela pondera a decisão do marido:

Eu até nem sei que que o falecido foi inventar, nós ia tão bem lá. Não sei porque que ele deu na cabeça de querer...convidaram muito, ajeitaram ele pra prantação de arroz, que nós ia pra lá né, Santa Catarina, ia prantá arroz, que eles começaram a dizer que dava mais lucro, que dava mais lucro...aí quiseram ajeitá ele e ele inventou, mas depois minha mãe tirou da cabeça dele. Daí ele comprou ali. Mas nós ia bem.

Já na Barra do Ouro, eles abriram uma pensão na atual Rua do Comércio, um ponto central e por onde passavam muitos viajantes. Foi lá que conheceu o segundo marido

roça?

F: E quando a senhora veio pra cá vocês pararam de lidar na

G: A-hã. Daí minha mãe ...o falecido, o falecido era muito por ela, né, e daí ela mandou que ele comprasse ali, botasse uma pensão, diz ela, vocês vive numa pensão, com os filho, daí ele quis, mas foi pouco tempo porque...pouco tempo nós trabaiemo ali junto, que ele morreu com quarenta ano. Quando ele casou ele tinha vinte e cinco. 
F: Então a pensão já era da sua família?

G: Já. Daí eu fiquei trabaiando do mesmo jeito, eu tava com as criança já grandinha, e continuei. E depois arrumei outro, né, esse último que morreu já faz oito anos...

F: Ele era viajante, não era daqui?

G: Não, ele não era, ele era do DAER... F: Mas

passou por aqui...

G: É, ele trabaiava aqui, nessa serra aí, e parava...foi parar mesmo lá em casa. Ele era solteiro. Tinha vinte anos.

F: E a senhora tinha quantos? G:

Trinta e oito.

F: Já com os três filhos?

G: Com os três filhos. O Diles ele que criou. Não tinha seis anos ainda. O Diles tá com 62. O mais velho tá com 67, e a mãe da Marta tá com 64. Fez ontem, ontontem.

Dona Geni é uma mulher forte, de fala e de espírito. Sua força interior contrasta com a fragilidade do corpo no presente. Dona Geni tem 86 anos e é uma das mulheres mais antigas na comunidade

\section{Pedro Witcoski}

Tinha mais duas ferraria ali, uma era aqui outra lá adiante, tinha três ferrarria ali, e hoje não tem nada, nada. Moinho tem só um lá adiante. Mudando tudo. O pessoal foi saindo, não dava de trabalhar na lavoura. Foram indo pra cidade, e agora apertou na cidade, né? 


\section{Enquanto conversava}

com Joanin, sua nora me contava que sua irmã era casada com o filho de Pedro Witcoski, outro antigo morador da Barra do Ouro. Já tinha ouvido falar nele como um homem de sabedoria, que fazia cestos e artesanatos. Depois de Joanin,

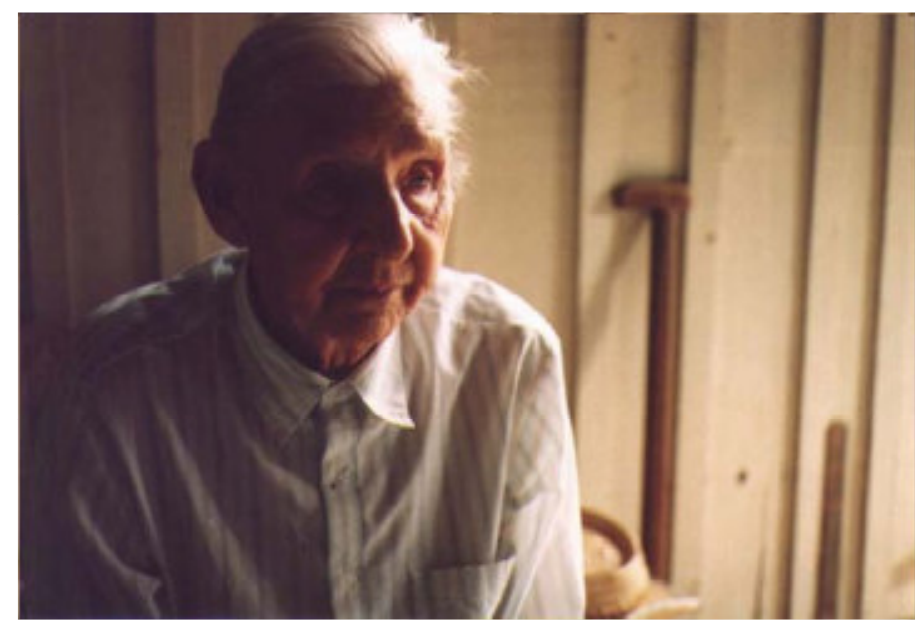

Pedro era o mais antigo morador da Barra do Ouro. Dona Geni também já havia me falado dele: eles eram cunhados, da parte de seu primeiro marido.

Cheguei em sua casa num domingo chuvoso depois de entregar as fotos a Joanin. A casa estava cheia: filhos vindos de longe, primos, sobrinhos, netos e bisneto. Esperei Seu Pedro na sala, imaginando sua fisionomia. Muito alto e magro, de cabelos brancos ele chegou me cumprimentando, sentou-se na poltrona vermelha à minha frente, e começamos nossa conversa. Seu Pedro tinha alguma dificuldade em escutar, o que fazia com que eu me aproximasse a cada pergunta ou comentário. A camisa branca engomada mostrava uma elegância do tempo antigo, mas os remendos no punho e nas costas remontavam uma vida dedicada ao trabalho.

Pedro, apesar de ser o menos falante dos entrevistados, é referência na fala de todos os outros. Parece ter sido um homem importante na comunidade, embora não fale muito de si mesmo. Sua narrativa por vezes me lembrava a de um cientista social: falava das coisas do tempo antigo não de forma pessoal, colocando sempre o que "se fazia", e não o que ele fazia. Pedro fechava suas narrativas com uma espécie de análise, simples, mas que sintetizava o movimento e a causa das mudanças.

Aos 92 anos, Seu Pedro impressiona pela altura e rigidez do corpo. Não é um homem enrugado ou curvado. Sua voz é grossa; a fala, rápida e objetiva. Filho de 
imigrantes poloneses, Pedro nasceu no Rio do Ouro e lá viveu até os 84 anos. Pai de onze filhos, Seu Pedro conta os tempos difíceis da colônia:

F: E o senhor saía daqui, viajava, ia pra serra...

P: Eu saía, tinha tropinha . Eu tinha os animal, e aí levava produto lá pra, pra Santo Antônio praqueles lado, mas tudo pra serra. Nos carguerinho, tocando. E quando vi depois não dava, a família aumentando, e eu não ganhava pra sustentar, aí tive que vender. Vendi as mula e comprei terra, fiquei trabaiando na terra.

\section{F: Comida não faltava}

P: Não , comida não faltava. Eu ia mais magro um pouco, mas pra faltar comida nunca faltou. Mas eu tava dizendo que a gente comia feijãozinho com batata inglês, nem arroz não tinha pra botar, não dava, pegava anos de seca ali, não era muito fácil de a gente viver. E hoje em dia se vê tudo em abundância, né?

Durante a entrevista, Seu Pedro falava mais das estórias e costumes do tempo antigo e nas transformações de hoje, do que propriamente sua vida. Respondia com objetividade quando perguntado sobre sua mulher, falecida há 22 anos, filhos e da sua vida como colono e filho de imigrantes. Perguntei a ele sobre o incêndio da igreja da Barra do Ouro.

F: O senhor lembra quando uma igreja ali na Barra do Ouro pegou fogo?

P: Lembro, nós trabaiamo pra fazer aquela igreja. Depois queimou, nós reformemo de novo, trabaiando tudo e foi reformada.

F: E como foi que ela queimou?

P: Não se sabe. Foi de noite. Mas foi de madrugada que ela se incendiou tudo. Mas botaram fogo de noite. E o padre nem tava ali na paróquia quando que queimou a igreja. Telefonaram pra ele, ele tava lá pro lado de Caxias, a gente telefonou lá e tava lá, na casa dos parente 
dele. Foi triste aquela vez quando queimou a igreja, sim. Muita gente disseram ah, eu não alcanço mais a igreja como tava antes, aí o padre disse não, isso com pouco tempo nós levantemo a igreja. E foi pouco tempo, oito mês já rezaram a missa.

F: Quem construiu foi o pessoal daqui?

P: É, todo o pessoal daqui trabaiava. Eles escalavam, duma linha 4, 5 por dia, outros dali, tavam tudo trabaiando.

F: E ela ruiu toda, não sobrou nada?

P: Ficou só as parede. O resto queimou tudo. Até o sino que tava em cima, lá na torre, aquele também desceu.

Seu Pedro permanecia sentado e solícito enquanto eu lhe fazia perguntas. Mas quando me distraía na conversa com um de seus familiares, ele levantava ou fechava os olhos em sinal de cansaço. Falando de sua vida hoje, ele comentou que pouco saía, porque sentia tontura e a idade já lhe era alta.

...tô ali perto da igreja, não posso ir à missa nem nada. Quando a gente era mais novo ia visitar os doente, ia em velório, enterro, e hoje já não...pra mim não tem mais nada.

Há 8 anos, Seu Pedro veio para a Barra do Ouro em virtude de sua doença. É onde vive hoje, com o filho mais novo e a nora.

\section{ARLINDO ADAMATTI}

Fotógrafo profissional é raro como as mosca branca. 
Quando pela primeira vez

Dona Geni me mostrou a fotografia do incêndio da igreja, percebi no canto esquerdo uma assinatura: Adamatti, ela comentou que era um fotógrafo que trabalhava por ali, além de outro, de nome Francelino De Carli. Não imaginava que

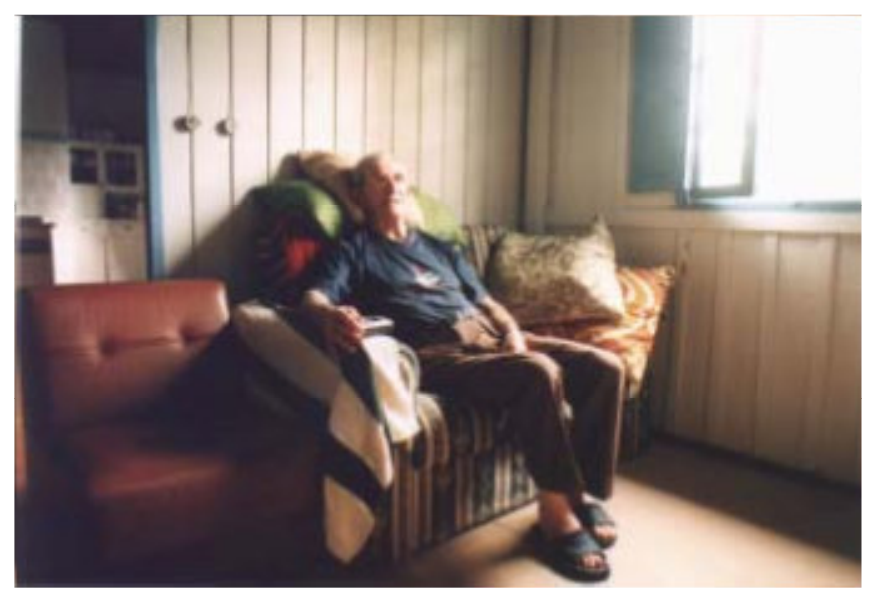
estivessem vivos. De Carli de fato não estava; conversando com uma das noras do Seu Pedro Witcoski descobri que este havia falecido ainda moço. Arlindo Adamatti, no entanto, estava vivo e morando em Maquiné. Procurei a irmã mais nova de seu Arlindo, dona de um restaurante em Maquiné. Ela comentou que ele começava a mostrar sinais do Mal de Parkinson, mas que ainda assim falava bastante, e tinha muita história pra contar. Indicou sua casa, e assim eu marquei uma visita com a filha dele. Minhas expectativas eram grandes, afinal o fotógrafo que havia registrado tantas cenas da Barra do Ouro estava ainda vivo! Cheguei à casa de seu Arlindo na companhia de dois amigos: um fotógrafo portoalegrense e um agricultor de Maquiné, com quem seu Arlindo costumava conversar longamente.

Ele estava sentado na poltrona ao lado da janela. quando levantou para nos cumprimentar, chamou-me a atenção sua altura: assim como seu pedro, era alto e magro. não tinha uma aparência frágil, apenas doce e receptiva. seu arlindo nos recebeu com um largo sorriso. parecia não se importar em conhecer as razões que me levavam até ele. quando disse que era fotógrafa, tornamo-nos cúmplices: conversávamos como dois colegas de profissão. Durante toda a entrevista, ele falava muito das técnicas fotográficas, tipos de filmes e câmeras. pouco dizia sobre a família, o rio do ouro e a vida na comunidade. é como se sua vida tivesse começado quando começou a fotografar: seu arlindo é um apaixonado pela fotografia, e que ressente ter abandonado a profissão. 
... a minha paixão era de aprender a fotografia. me deu na idéia assim que eu queria aprender aquilo.

Sua imagem no tempo antigo me lembra a figura de um viajante, que passa pelos lugares, encanta as pessoas, dá-lhes coisas que não possuem e segue viagem, segue o destino aventureiro de um fotógrafo viajante. seu arlindo é o mais novo dos entrevistados, mas desde que ficou doente parou de trabalhar. hoje, com 78 anos parece ter pouca autonomia e é cuidado pela filha.

seu arlindo começou a trabalhar como fotógrafo no dia 29 de fevereiro de 1949.

Comecei a trabalhar com uma máquina de tripé (...) hoje chamam aquilo lambelambe, mas era uma máquina de chapas, filpac, filme e pra trabalhar e revelar, uma caixa de botar revelador e tudo, fabricava na hora dentro assim.

Foi em porto alegre que seu arlindo aprendeu a fotografia, com um professor que havia chegado da itália.

Então eu sabendo que esse homem era um bom fotógrafo, de vez em quando ele vinha, mas ele quando veio trabalhar, me ensinar pra mim não sabia tudo aquilo que eu aprendi porque depois eu fui por livro, que ele sabia fazer bem feito, mas era tudo, com ampliador nada, aumentava assim um pouquinho, que até aquele ampliador que ele começou a trabalhar era feito manual por um outro já feito daqui mas não era importado, só a lente. E quando eu peguei eu já comprei ele feito, eu comecei a revelar, a ampliar, reproduzir, e...eu peguei assim, uns cinco ou seis dias eu já comecei a fazer fotografia. Bater, bater, revelar, secar, cortar, entregar, pra mim aquilo foi uma coisa que eu tava sabendo. Eu só tinha vontade de aprender. É, em três dias ele disse para a mulher dele, ó, depois de amanhã pode mandar o Arlindo embora, dá...bom ele precisa o livro das químicas, tudo, tem que tomar nota, vê como é que tu vai fazer...eu saí dali há três dias que eu...bom, nós tinha os dia todo, e de noite ia muitas vezes até meia-noite. 
Tem que ser assim, tem que ser assado...já comecei sair fazendo foto. Em oito dias eu já vim pra casa que eu morava aqui, quando eu voltei já levei um punhado já de fotografias bem feitas, já. É, ele ficou, pah! Ele ensinou acho que uns 50, mas daqueles não saiu nem dez, nem cinco. Sim é que começavam a fazer, pegava um jeitinho, mas de repente estragava tudo, o que que ia fazer? E pra mim não, pra mim, fácil, fácil, fácil. Agora já faz dois anos...mais um pouco que dois anos, que eu não...

Quando perguntei o quê ele fotografava, seu Arlindo riu, contando que fotografava "tudo o que é documento, tudo o que é reproduções, velha, antiga, amarelando que começava a se deteriorar, e casamentos, batizados, comunhões, corrida de cavalo..."

F: Mas por onde isso? Aqui na região?

A: Aqui no Rio Grande, aqui por exemplo Maquiné... bom, aqui até Santa Catarina, até onde me chamavam pra Osório, até onde me chamavam pra Santo Antônio, até onde me chamavam Paradouro, essas linhas tudo por esses morro aí, nesses pico de cupim de morro aí, um enforcado no mar, enforcado num pau, outro pendurado lá num galho de pau lá em cima, outro despedaçado em pneu de carro, que passaram por cima, tudo essas coisa assim. Tudo foto pro foro. Fotógrafo pra detetive, foto pra copiar coisa, detetive, secreta, de roubos, assalto, tudo que não prestava tocava pra mim..

\section{F: O senhor ia com o equipamento nas costas?}

A: Não eu tinha...não trabalhei nas costa, só assim pertinho. Eu comprei uma bicicleta primeiro fazer voltinha, e depois uma moto, uma Java 24 cavalo, era uma máquina. Ah, eu trepava nesses bico duma estradinha assim e ia embora, por cima das ponte...e andava mais do que essas máquina que anda agora. 
Com o passar do tempo, Seu Arlindo já era chamado nas festas, batizados e casamentos porque "dava sorte", como se ao tirar a fotografia, eternizasse o momento de alegria que era ali retratado. Ele menciona que tinha um imã que o puxava para os lugares: ou era mesmo sua destreza na profissão.

\section{Redescobrindo a Barra do Ouro}

Situada na região conhecida como litoral norte do Rio Grande do Sul, a Barra do Ouro é hoje distrito do município de Maquiné ${ }^{6}$. Conhecido pelas belezas naturais e pela diversidade de seu ecossistema, o município faz o elo de ligação entre a serra e o mar, limitando-se com São Francisco de Paula, ao norte, Osório, ao sul, Capão da Canoa e Terra de Areia, a leste e Riozinho, Rolante e Santo Antônio da Patrulha, a oeste. De Maquiné até a Barra do Ouro, a estrada mergulha no vale em direção à serra: no caminho, extensas áreas de várzea, entrecortadas por linhas que se estendem até o fundo dos muitos vales que circundam o município.

\section{Um tempo latente}

Da rua plana e larga, avistam-se morros em todas as direções. O verde circunda e acolhe esse ponto central na cultura e geografia da Barra do Ouro, que é a Rua do Comércio. Nela estão a igreja, o salão paroquial, o campo de futebol, o clube, o posto de saúde, a telefônica, os bares e mercados. Ao lado esquerdo de quem chega, vê-se duas ou três ruas paralelas já na subida do morro. Ao lado direito está o rio, que corre ao lado da rua principal, agregando casas, escolas e igrejas ao longo de toda a região.

A Rua do Comércio já abrigou correio, moinhos, ferrarias e até um cartório. Fotos antigas mostram apresentações teatrais, desfiles e bandas de música na rua, quando esta ainda era de chão batido. Afora algumas modificações no espaço, como a ampliação do salão paroquial, a construção de outros prédios que fogem ao estilo das edificações antigas, e o asfaltamento da rua, a Barra do Ouro de hoje permanece muito semelhante àquela de outrora.

\footnotetext{
6 Maquiné emancipou-se do município de Osório em 1992, abrangendo os distritos de Morro Alto e Barra do Ouro. A população do município é de 7650 habitantes, sendo que $70 \%$ vive na área rural e o restante nos núcleos urbanos (censo 95/96).
} 
A rua que é ainda do mesmo tamanho - nem maior, nem menor - , é ainda o espaço central na vida dessa comunidade. Ela é a referência do tempo antigo, em que a cidade era o centro econômico e cultural da região, e onde se fazia presente uma intensa dinâmica social. Uma tentativa de sustentar o presente com os resquícios da época de ouro da Barra? Talvez. Mas a manutenção de uma fisionomia que recupera o passado - mesmo que muitos elementos tenham sido efetivamente destruídos - traz um sentido de tempo parado, estanque, como se a cidade tivesse virado as costas para as modificações do presente e para as possibilidades do futuro.

Antiga colônia Marquês do Herval, conhecida também como colônia Rio do Ouro, a Barra conheceu um período de grande desenvolvimento econômico, social e político. Tem-se registros, segundo recenseamento feito na época, de que em 1920 a população de Marquês do Herval era de 2336 habitantes, contra 1500 contabilizados no censo 95/96. A diminuição drástica da população da Barra do Ouro nos leva a crer que o distrito vive hoje uma situação de

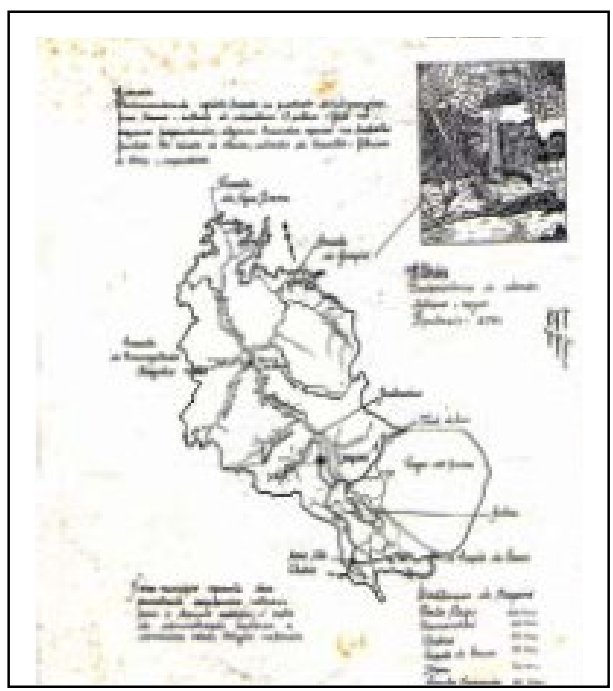
entropia: populacional, econômica e cultural.

Conforme nos diz Hannah Arendt, “...é o futuro que nos impele de volta ao passado. Do ponto de vista do homem, que vive sempre no intervalo entre o passado e o futuro, o tempo não é um contínuo, um fluxo de ininterrupta sucessão; é partido ao meio, no ponto onde 'ele' está; e a posição dele não é o presente, na sua acepção usual, mas antes, uma lacuna no tempo, cuja existência é conservada graças à 'sua' luta constante, à 'sua' tomada de posição contra o passado e o futuro". Talvez seja justamente a ausência de uma perspectiva futura que faz com que a cidade viva hoje um estado de latência, como se estivesse à espera de algo que a fizesse retomar seu movimento anterior. 


\section{A época de ouro da Barra}

O marco do início da colonização na região de Maquiné ${ }^{7}$ foi a chegada, por volta de 1830, de Antônio Leonardo Alves, procedente de Desterro, antiga Florianópolis. Cultivando cana-de-açúcar e utilizando trabalho escravo, foi ele quem deu o primeiro nome que se tem registro do lugar: Fazenda Leonardo. A necessidade de continuar o povoamento intensivo na região fez com que o Governo Provisório da República fundasse, em 1890, a Colônia Marquês do Herval, que recebia, nesse mesmo ano, um total de 948 imigrantes poloneses. Muitos desses imigrantes não permaneceram na região, seja devido a uma inadaptação à natureza e ao clima locais, ou por serem outros seus destinos.

Segundo nos relata Seu Pedro, descendente de poloneses e morador da Barra do Ouro:

Eles vieram, se acamparam aqui em Osório e depois então foram saindo, pra Colônia. Muitos ficaram aqui, outros já foram lá pra Passo Fundo, outros pro Paraná e aí ficou tudo espalhado. Então meu pai falava que ele não queria ficar ali, queria ir pra Passo Fundo. E por fim os cunhado dele foram pra lá, e de lá já foram pro Paraná e fiquemos por aí. Fiquei ali na morada velha 84 anos eu vivi naquele lugar.

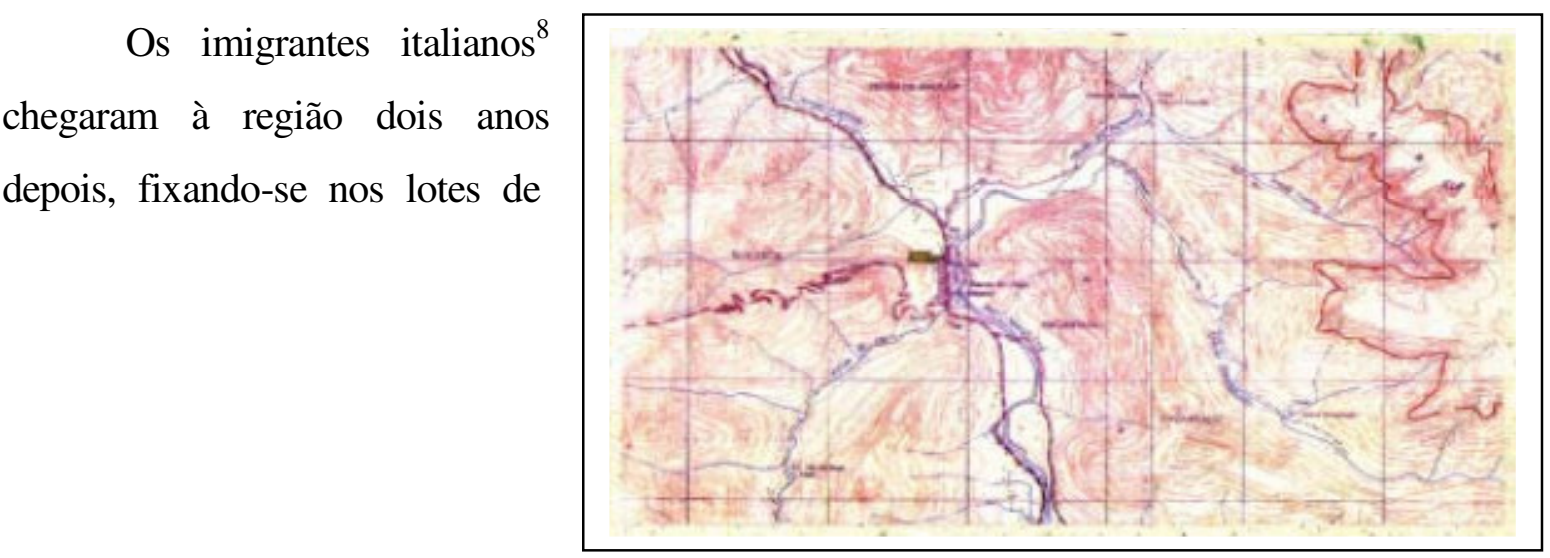

\footnotetext{
7 Há registros de presença indígena na região do litoral norte de 4 a 6 mil anos atrás. Mais recentemente, foram identificados dois grupos que já viviam organizados em aldeias, habitando a região de Maquiné e toda a faixa litorânea entre o mar e a encosta da Serra Geral: os Arachãs e os Carijós, ambos grupos semi-nômades e com língua pertencente à família Tupi-Guarani. Por volta de 1600, teve início no litoral gaúcho o período bandeirista, responsável pela expulsão e extermínio de muitos dos grupos indígenas. Por isso, os primeiros colonizadores pouco encontraram da forte presença indígena na região. Ainda assim, a região hoje abriga uma das mais importantes aldeias Mbyá-Guarani, em uma área de aproximadamente 2 mil hectares, entre ao municípios de Maquiné, Riozinho e Caará.

8 Alguns documentos e relatos de antigos moradores comentam a chegada de imigrantes alemães na mesma época, mas são poucas as referências a esses imigrantes.
} 
terra da Colônia Marquês do Herval. Os italianos eram, em sua maioria, provenientes das colônias de Caxias do Sul, as quais já se encontravam saturadas. O clima mais ameno e a alta fertilidade do solo atraíram os colonos e determinaram um período de produtividade e riqueza na região. No ano de 1895 foi inaugurada a primeira igreja e já se bebia vinho produzido ali. Nessa época, a população da colônia que é hoje a Barra do Ouro contava com 1301 habitantes, e na sede já existiam casas comerciais, ferraria, sapataria e fábrica de cerveja. A construção da estrada que fazia a ligação de Marquês do Herval com a Vila de Taquara, em 1904, dinamizou ainda mais a vida na colônia, facilitando as tropeadas e carretas que levavam a produção da colônia a outros lugares. Em 1910 foi construída a estrada que é hoje conhecida como RS 484 ou Serra do Umbú, saindo de Conceição do Arroio (hoje Osório), passando por Marquês do Herval e se prolongando até São Francisco de Paula. Essa estrada foi decisiva para o escoamento da produção e principalmente na consolidação da Colônia Marquês do Herval, que fazia a ligação entre a serra e o litoral, como um centro político, cultural e econômico de toda a região.

Assim como na maior parte das colônias italianas no Rio Grande do Sul, as terras recebidas pelos imigrantes eram divididas em Linhas ou Travessões, de traçado regular e retangular (Posenato, 1983). A Barra do Ouro e todo o município de Maquiné têm na divisão por linhas uma importante característica. Pedra de Amolar, Forqueta, Garapiá, Pinheiro, Encantada, Ligeiro, Cerrito e Rio do Ouro são algumas das linhas que, como todas as outras, avançam desde a estrada até o fundo de algum dos vales que constituem a Serra Geral.

À época da chegada dos imigrantes, essa forma de ocupação e distribuição dos lotes colocou-os em uma situação de isolamento a qual não eram acostumados, reduzindo sensivelmente as possibilidades de convivência e trocas sociais (Bertussi, 1983, p.133). O convívio acontecia nos pontos de convergência dos imigrantes: nas casas de comércio, no moinho e na capela. Esta última constituiu-se como o espaço onde o colono pôde reconstituir seu mundo cultural, através da religião. Os colonos tinham uma forte preocupação com a organização religiosa, seja em casa na reza do terço e com o ensino do catecismo às crianças, seja na comunidade com as construções cuidadosas do cemitério, do capitel e da capela (Posenato, 1983, p.46). Cada linha tinha uma capela, quando não duas ou mais. Assim, a vida na colônia estava intrinsecamente ligada à religiosidade. Ainda 
hoje, a religião é o eixo da cultura desse imigrante, mesmo que o relato dos antigos reforce que a religião hoje está muito "decaída". As festas religiosas são amplamente comemoradas, e cada linha mantém sua capela organizada. Em algumas linhas, como o Rio do Ouro e Pedra de Amolar, as capelas foram reformadas, em alguns casos ampliadas até, substituindo-se a antiga construção de madeira por construções de alvenaria, acompanhadas de grandes salões paroquiais, que são, de fato, o espaço de encontro dessa comunidade.

\section{Os novos tempos}

A linha do Rio do Ouro, a de maior proximidade do núcleo urbano da Barra, foi uma das localidades mais habitadas do município. Coincidência ou não, todos os informantes dessa pesquisa nasceram ou viveram próximos ao curso desse rio. Geni Soares Carpinski, Pedro Witcoski, Arlindo Adamatti e João Demoliner ali moraram cada um à sua maneira, por um curto período da vida ou por toda ela, junto a aproximadamente mais sessenta famílias ${ }^{9}$ que habitavam a linha. Cada um com uma estória, um motivo, todos deslocaram-se dali para a Barra do Ouro, e guardam na memória o "tempo antigo" do Rio do Ouro como uma época de prosperidade e vida comunitária. Hoje, não restam mais que sete pessoas vivendo ali. De certa forma, os entrevistados personificam o movimento de abandono da linha, por volta da década de 70, seja devido ao esgotamento do solo, à emergência de um novo modelo produtivo ou mesmo à construção da BR 101, que deslocou o foco social, político e econômico da região para Maquiné e Osório. O esvaziamento da linha do Rio do Ouro reflete uma situação vivida por toda a região colonial do Rio Grande do Sul, onde nas décadas de 40 e 50 se fez sentir um decréscimo nos rendimentos obtidos com os cultivos, especialmente batata, feijão e milho, característicos do sistema colonial de produção.

Sobre o esvaziamento das linhas, Seu Pedro comenta:

o rio do ouro não é muito grande. mas era povoado. cada duas colônia era uma família que morava. aqui tinha a encantada, que também era uma linha

\footnotetext{
9 Nos relatos dos entrevistados e moradores que se referem ao Rio do Ouro, o número de famílias que habitava a linha há pelo menos trinta anos varia de 60 a 100, embora a maioria se refira a 60 ou 66 familias.
} 
comprida. por fim o pessoal ficava apertado, né, pode ver, de uma colônia tinha meia, e como é que vai viver em meia colônia? aí foram saindo, foram saindo e indo pra caxias, pra outros lugar. a terra era boa pra trabalhar. mas depois os pais morreram, os filho foram ficando, ficando e foi apertando, aumentando o povo e a terra pouca, muita gente, foram saindo, tudo embora. e agora não deixam plantar roça, do que que o povo vai viver? tem que sair, tem que ir embora! deixar as terra e ir embora!

As numerosas famílias dos imigrantes, que tinham 10 a 12 filhos, representavam, além de mão-de-obra suficiente para o trabalho, uma possível diminuição no tamanho das colônias. Se a terra fosse dividida entre todos os filhos, não haveria como sustentar esse modelo de produção. Uma das saídas encontradas foi o sistema do "minorato", onde os filhos que primeiro casassem saíam em busca de novos lugares para morar, enquanto o filho que casasse por último, geralmente o mais novo, ficava como herdeiro das terras do pai.

Se na época não havia terra para que todos os filhos ficassem na colônia, hoje sobra terra para pouca gente. A geração que foi "expulsa" desse modelo produtivo colonial não mais voltou; na mesma época em que esse modelo mostrava sinais de exaustão na área rural, a área urbana e industrial começava a se consolidar. A região do Vale do Rio dos Sinos se firmava como uma zona industrial à procura de mão de obra. Alguns moradores que à época saíram do Rio do Ouro para tentar a vida na cidade, contam que nas longas filas de desempregados que se formavam nas indústrias, abria-se uma porta de onde perguntavam: “quem é colono?”, “quem é agricultor?”, e este logo passava ao começo da fila. Nesse período de êxodo rural, o colono era valorizado como uma mão-de-obra que sabia trabalhar, que "não queria moleza". Se o jovem agricultor era expulso de um modelo produtivo, em outro era acolhido com honras.

Por outro lado, o próprio processo de envelhecimento das unidades produtivas que caracterizavam o lugar como colônia proporcionou o surgimento de uma nova dinâmica de trabalho, aumentando a diversidade de atividades existentes para aqueles que permaneceram no campo. A extração de samambaia, serviços de pedreiros, carpinteiros, empregada doméstica, diaristas nas lavouras, caseiros de sítios de lazer e arrendamento de 
terras são algumas das atividades que surgiram como alternativa ao modelo de agricultura colonial. Na fala de alguns moradores que ainda produzem percebe-se um desapontamento e uma certa perplexidade diante da nova realidade. Um agricultor local comentou o fato de haver casos de roubo de frutas e outros alimentos nas propriedades junto a Barra do Ouro, que segundo ele, não eram para consumo, mas para venda. Esse novo quadro que se coloca na Barra do Ouro é para alguns moradores devido à vinda de pessoas de fora, para outros, "é coisa de gurizada", uma resposta dos mais jovens que buscam ter dinheiro para comprar coisas e participar das festas em centros maiores, como Osório e Capão da Canoa.

A Barra do Ouro abriga também um espaço marginal dentro do núcleo urbano, chamado "beco". Quando perguntados sobre a localização do "beco" na Barra do Ouro, os moradores apontam para o fim da rua, na subida do morro. Os moradores do "beco" são os "pobrezinhos" ou "aqueles lá", e o lugar já se constitui para alguns numa referência para nomear aquilo que, no geral, não compartilha os mesmos códigos culturais estabelecidos pelos imigrantes na Barra do Ouro.

Ao falar sobre os moradores do fundo do Rio do Ouro, Dona Geni, antiga moradora do Rio do Ouro e que hoje vive em um ponto central da Rua do Comércio, faz uma comparação com os moradores do beco:

\footnotetext{
Bem no fundão, tinha, bastante gente tinha ali. Até tinha esses brasileiro ali, que são moreno, que moram ali, ali naquela rua de cima, umas morena ali que moravam lá que vieram morar aqui depois, saíram de lá vieram pra cá... E tem outra família também que mora beeem lá em cima, também que morava lá beeem no fundão.
}

Norbert Elias, no livro "Os Estabelecidos e os Outsiders” examina em uma pequena comunidade um tema que considera universal: a diferenciação de alguns grupos em relação a outros a partir de um sentimento de superioridade. Elias fala da existência de redes de famílias antigas, que mantém vínculos estreitamente solidários entre si, mas que consideram-se humanamente superiores aos moradores da parte vizinha, de formação mais recente na comunidade (2000, p.20). Essa diferenciação entre "os antigos" e "os vindos de fora" organiza a estrutura social da Barra do Ouro, ainda que os "outsiders" dali não sejam necessariamente pessoas vindas de fora: como foi dito anteriormente, essa pode ser uma 
metáfora para enquadrar determinado grupo de pessoas em uma condição e a partir daí, o outro grupo afirmar sua superioridade e coesão social. Distinções de etnias, religião, nível econômico e educacional, e a própria falta de coesão de um grupo em relação à outro podem ser motivos para que sejam considerados "de fora".

Hoje, apesar de a região ser conhecida como uma das mais férteis do estado, são poucas as famílias que produzem garantindo seu sustento. Vem se tornando freqüente a circulação de caminhões com produtos da Ceasa que levam até a Barra do Ouro frutas e verduras para o consumo dos moradores. Em algumas linhas mais afastadas, como o Forqueta, já existe uma feira, uma vez por semana, que vende frutas e hortigranjeiros. Esse fato me foi relatado com indignação por um agricultor enquanto comentávamos a diminuição do número de famílias que produzem para a subsistência. Para ele, é difícil entender que pessoas que tinham e ainda têm condições de plantar seu alimento ("ao menos um aipim, um milho...”), o comprem de fora.

No entanto, não é mais possível o plantio como se fazia antigamente, nos tempos das colônias. O sistema tradicional de cultivo da terra, com períodos de queima, roça e pousio, foi sofrendo restrições com a criação da Reserva Biológica da Serra Geral, em 1982, mas principalmente a partir dos anos 90, quando tiveram início as ações de fiscalização. Enquanto uma Unidade de Conservação, a Reserva restringe a utilização direta dos recursos naturais como a queima, a caça, a derrubada de árvores nativas, ou seja, os hábitos que marcaram historicamente a vida do colono, e que faziam parte de uma cultura de subsistência.

O município de Maquiné também está inserido na área da Reserva da Biosfera da Mata Atlântica, reconhecida nacionalmente pela UNESCO em 1992. Desde 1998, com a criação da Lei de Crimes Ambientais, a aplicação de multas vem se tornando cada vez mais freqüente, e o conflito entre agricultores e "fiscalizadores" também. Por "fiscalizadores", grande parte dos agricultores da região entende não apenas os funcionários que trabalham diretamente na Reserva (geralmente o diretor e mais duas pessoas), mas todos aqueles que adotam um discurso contra as queimadas, a caça , a derrubada das matas, a poluição do rio, ou a favor de novas práticas de cultivo da terra. Além do confronto e da dualidade homemnatureza, se faz visível um confronto entre os hábitos do passado e as condições do presente. 
Um agricultor local, que teve seu plantio reduzido, assim relatou a situação:

Agora, eu digo assim, isso aqui é uma coisa errada, porque como é que antigamente queimavam, faziam tudo, e não tinha nada, agora hoje tá tudo mato e tão proibindo por quê?

Nos últimos anos, um movimento de retorno ao lugar de origem se faz sentir. Muitos moradores que deixaram a Barra do Ouro para tentar a vida em outros lugares estão voltando, já aposentados, para usufruir de uma vida que, na época, não se fazia possível. Essa primeira geração que saiu de lá há 20, 30 anos, hoje volta trazendo consigo uma nova perspectiva para o lugar. É dessas pessoas que vêm a crítica ao "atraso" e à "falta de progresso" na Barra do Ouro. Nas palavras de Gilberto Velho (2001), essas pessoas atuam como mediadores culturais, cruzando fronteiras e comunicando espaços socioculturais distintos. A mediação é uma negociação contínua da realidade com referência a sistemas simbólicos, crenças, interesses materiais e imateriais. Ao voltarem a seus lugares de origem, os mediadores atuam como agentes de transformação de práticas locais.

Uma dessas pessoas é Antônia Carpinski, a Tonha, que deixou a Barra do Ouro depois do casamento para viver com o marido em Novo Hamburgo. Ambos eram naturais da Barra do Ouro, e há cerca de oito anos voltaram, já aposentados, passando a viver na casa da sogra, Dona Geni, que veio a se tornar minha principal informante neste trabalho. Tonha é referência em várias atividades com grupos de mulheres, como a Farmácia Caseira Comunitária Corticeira da Serra e a Pastoral da Saúde, e desde o início apoiou os trabalhos da ONG Anama, um grupo de fora que é visto com desconfiança por muitos moradores.

O mediador que nos fala Velho pode também ser tanto um morador local que experencia outras formas de vida, como um pessoa de fora, que transite por mundos sócioculturais distintos e transmita, de alguma forma, um pouco dessa bagagem cultural nos lugares onde passa. Minha posição na Barra do Ouro, enquanto pesquisadora era também de mediadora, entre dois diferentes mundos, os quais eu estava, de alguma forma, comunicando.

Sobre a receptividade desses mediadores na Barra do Ouro, é fácil perceber uma certa antipatia dos moradores em relação às pessoas que não são de lá, na linha do que foi 
colocado anteriormente como os "vindos de fora". Na viagem de volta de uma das minhas idas a campo, escutei a conversa de dois homens de meia idade que sentavam a minha frente no ônibus. $\mathrm{O}$ assunto eram as proibições e multas que os agricultores vinham sofrendo nos últimos meses, fato que era atribuído às modificações do presente ("agora com esse meio ambiente...") e à vinda de pessoas de fora, numa clara referência à ONG Anama, que discute e propõe ações na área ambiental. Dessa forma, a discussão e a responsabilidade pela nova dinâmica em que se encontra a Barra do Ouro são colocadas para fora da comunidade, como resultado de imposições externas. Mesmo quando o sentimento de mudança encontra-se no germe da própria comunidade, a coisa não se faz diferente. Agricultores que concordam em parte com as proibições, ponderando os danos causados ao meio ambiente, ou que buscam experimentar novas formas de cultivo da terra são chamados de "traidores" ou "loucos". É uma atitude de defesa e uma tentativa de preservar um modo de vida que, isolado e fechado em si mesmo, já não é mais possível.

As imposições sociais, políticas e econômicas podem ser cruéis sob determinados aspectos, mas não há como fugir delas: a natureza do posicionamento diante de uma situação - se contra ou a favor - importa menos que sua tomada de consciência. Os habitantes da Barra do Ouro têm hoje muitas questões do presente a confrontar com os hábitos do passado, questões que exigem uma constante negociação entre os agentes da mudança e uma comunidade que lamenta não viver mais o tempo antigo.

\section{Memória, Fotografia e Narrativa}

\section{Lembranças são fotografias?}

Havia nos entrevistados a especificidade de não apresentarem, ao longo de suas vidas, uma relação de familiaridade com a fotografia, seja por fazerem parte de uma geração antiga, ou pela própria distância do centros focalizadores dessa tecnologia. Com exceção de Seu Arlindo Adamatti, que fora um dos únicos fotógrafos da região de Maquiné e Litoral Norte, os entrevistados possuíam poucas fotografias, e não tinham o hábito de organizá-las em álbuns. Dona Geni, por exemplo, tinha as poucas fotografias emolduradas na parede ou guardadas em um envelope de carta. Miriam Moreira Leite (2001), no livro 
sobre retratos de família, coloca que as imagens dialogam com os lugares da memória onde elas estão inseridas e estes lugares podem fazer com que estas exprimam diferentes sentidos. Um retrato de família, por exemplo, quando em um jornal, museu ou almanaque, expressa um significado que difere em muito daquele onde as imagens são vistas apenas pelos que as conservam e as contemplam. De qualquer forma, seja guardadas em álbuns ou em qualquer outra forma particular de organização, essas imagens estão imbuídas de um valor de culto (2001, p.160).

Mas quando as imagens são organizadas em álbuns, o que aparece é uma tentativa, um esforço no sentido de organizar o tempo e a memória de acordo com os registros fotográficos, encadeando os acontecimentos e personagens do passado e elaborando uma construção narrativa acerca deles. Formas diferentes de se organizar as fotografias (em caixas de sapato, porta-retratos, envelopes, arquivos, etc) não deixam de simbolizar diferentes formas de se organizar o passado. As poucas imagens fotográficas que os entrevistados possuíam e mesmo a ausência destas imagens no momento da entrevista, elucidava o fato de que, nesse caso, elas eram dispensáveis na reconstituição da memória dessas pessoas.

Para um fotógrafo, ou qualquer pessoa que tenha se habituado com o registro fotográfico dos momentos marcantes e mesmo cotidianos de sua vida, é inquietante pensar sobre quais imagens habitam a memória de alguém que não teve esse aporte visual. Phillipe Dubois em "O ato fotográfico" (1993, p.314), menciona que a fotografia é o equivalente visual exato da lembrança. Ao olharmos uma fotografia, não vemos apenas aquela que temos em mãos, mas todas que se desencadeiam na memória e no imaginário a partir dela. Se a imagem fotográfica não é exatamente um equivalente, é com certeza o instrumento que mais propicia à livre evocação das lembranças. Por ser uma imagem estática, que não prende ou conduz a lembrança, a fotografia permite o ir e vir da memória, possibilitando o surgimento e o encadeamento de infinitas e diferentes imagens mentais. Quando nos deparamos com a imobilidade de uma imagem fotográfica, nossa mente é chamada a movimentar-se. Mas uma imagem parada não é uma imagem eternalizada: conforme coloca Flusser (1998, p.28), as imagens não eternalizam eventos, mas os substituem por cenas. Os eventos, dessa forma, não perdem sua característica viva e temporal, sendo constantemente modificados, seja no momento presente, seja na evocação da memória. 
Quando Dubois concebe a fotografia como o equivalente visual da memória, possivelmente esteja falando do tempo que é comum a ambas, um tempo mágico e circular. Ao nos lembrarmos de um momento vivido, essa lembrança raramente acontece de forma linear; antes, as situações encadeadas pela memória podem ter acontecido em tempos completamente diferentes e estarem ligadas por sensações, sentimentos, cheiros, etc.. De maneira análoga, a fotografia não vive um tempo linear. Como explica Flusser (apud Guran,2000, p.158) “(...) este espaço-tempo próprio da imagem fotográfica não é outro que o mundo da magia - mundo onde tudo se repete e onde toda e qualquer coisa participa a um contexto de significação".

Para aqueles que possuem registros fotográficos situando diferentes momentos da vida, certamente a fotografia funciona como um ponto de partida na evocação das

lembranças. É comum ouvirmos que uma pessoa se lembra de um acontecimento porque tem uma fotografia, ou seja, porque já reviveu o episódio na memória ao ver a fotografia, que é, nesse caso, um elemento externo e material que induz a pessoa ao ato de lembrar-se. Da mesma forma, também é comum esquecermo-nos dos momentos que não fotografamos. A linguagem fotográfica auxilia, portanto, na reconstrução de uma narrativa histórica e memorial, seja da vida de um sujeito ou de um grupo. Mas independente de possuirmos ou não registros visuais, é o sentimento que determinada situação vivida provoca em nossa pessoa que nos coloca frente à necessidade de a guardarmos ou não em nossa memória.

\section{Imagens compartilhadas}

As imagens fotográficas podem muitas vezes ser o aspecto material que conecta as lembranças a uma comprovação fatual, atuando como um documento ou um testemunho visual em sua relação com a memória (Kossoy, 1989, p.98). É comum em entrevistas que buscam reconstituir aspectos do passado, a utilização de fotografias como uma forma de pontuar as narrativas. Esse mesmo sentido de testemunho pode também ser desempenhado pelo coletivo, pelo grupo que compartilhava um estilo de vida semelhante, em um mesmo lugar e uma mesma época.

Halbwachs (1990) menciona que, quando alguns aspectos de nossa memória permanecem obscuros, apelamos aos testemunhos para fortalecer, debilitar ou completar aquilo que já sabemos sobre um evento. A confiança na exatidão de um acontecimento 
aumenta na medida em que podemos apoiar nossas impressões não apenas na nossa memória, mas na memória de outras pessoas ou de um grupo.

Um sentido coletivo de memória permite uma certa homogeneidade nos relatos de um mesmo lugar, ainda que vistos sob a ótica do sujeito, de acordo com sua experiência particular de vida. Dona Geni e Seu Pedro, por exemplo, apresentam narrativas bem distintas acerca de uma situação comum: a vida nas colônias do Rio do Ouro. Dona Geni se refere à época em que viveu no Rio do Ouro como um tempo de fartura

Nós tinha milho dum ano pro outro. Quando colhia um novo que plantou ainda tinha milho velho, sempre. Tinha muito porco, muita galinha, mas tinha muito milho também. Nós comprava pouca coisa, muito pouca coisa. (...). Nós tinha arroz, nós colhia arroz pro gasto, tinha trigo, nós moía a farinha, tinha milho, fazia a farinha, tinha o feijão, carneava o porco tinha banha, nós comprava muito pouca coisa. (...). Eu até nem sei que que o falecido foi inventar (de sair da colônia), nós ia tão bem lá.

Seu Pedro, que viveu por mais de 80 anos no Rio do Ouro, fala bastante da época das colônias do Rio do Ouro, mas ao contrário de Dona Geni, relata uma vida difícil e sofrida para o colono. Segundo ele,

Tinha anos ali a gente pegava anos ruim, o feijão valia 6, 7 mil réis (...) Milho também, 5, mas pegava uns ano ruim ali que não dava pra gente se defender, passava mal até ali, muita gente passava quase fome. Hoje em dia se vê sobrando de tudo, mas naquele tempo, óia, se comia feijãozinho com batata inglês. Arroz não dava, trigo quando dava dava, e tinha anos que não dava nada. Foi uns ano brabo pro povo viver ali.

Apesar de compartilharem uma mesma época e um mesmo lugar, as experiências de vida podem ter sido marcadamente diferentes. Gilberto Velho (1994), quando fala de sociedades complexas, aponta a coexistência de diferentes estilos de vida e visões de mundo, em função de uma fragmentação e diferenciação de papéis e domínios. Assim, também a experiência é fragmentada: o indivíduo, ao longo de sua vida, atravessa fronteiras e transita por domínios, vivenciando em cada um deles diferentes códigos ético- 
morais e visões de mundo. Essa trajetória do indivíduo, composta de uma multiplicidade de referências, é o que leva à metamorfose, que é a mudança individual a partir de determinado quadro sócio-cultural. Segundo o autor, a diferença no nível do discurso e das representações não está colada às fronteiras sócio-econômicas: o que ocorre é uma negociação da realidade em múltiplos planos.

Dessa forma, uma mesma experiência - por exemplo, o trabalho na roça - é vivenciada e posteriormente incorporada à memória de acordo com a trajetória e as referências de cada sujeito. Segundo Halbwachs (1990), a sucessão de lembranças de uma pessoa é sensivelmente influenciada pelas relações que esta mantém com os diversos meios coletivos, e portanto, pelas transformações pelas quais esses meios passam. Com isso podemos compreender esses diferentes relatos como respostas frente às modificações ocorridas em um lugar significativo para a vida de ambos. Se hoje a linha do Rio do Ouro representa uma paisagem de abandono, em contraposição ao que foi na época das colônias, essa transformação - de paisagem e de sentido - precisa ser acomodada num conjunto de lembranças, seja na crença de que a vida hoje é melhor, ou de que aquele tempo sim é que era bom.

A memória coletiva, diz Halbwachs, tira sua força e sua duração no fato de ter como suporte um conjunto de indivíduos que se lembram, enquanto membros do grupo. Dessa massa de lembranças comuns, e que se apóiam umas nas outras, cada lembrança aparece com maior ou menor intensidade para cada indivíduo. Daí a afirmação do autor de que “cada memória individual é um ponto de vista sobre a memória coletiva, que este ponto de vista muda conforme o lugar que ali eu ocupo, e que este lugar mesmo muda segundo as relações que mantenho com outros meios" (1990, p.51).

Assim entendemos porque Seu Arlindo, que viveu no Rio do Ouro até os 22 anos de idade, fale pouco da linha. Para ele, o período em que lá morou talvez tenha sido vivenciado com menor intensidade do que sua posterior vida adulta. Foi apenas na última entrevista, quando mencionei que ele era o único entrevistado que não havia morado no Rio 
do Ouro, que para minha surpresa, ele disse que havia nascido lá. De lá saiu para o mundo: foi para o quartel, conheceu pessoas de outros lugares, e foi a Porto Alegre aprender fotografia. Só voltou para a linha no ofício de fotógrafo, registrando casamentos, aniversários, caçadas, mortes, etc. O trabalho com fotografia é, para ele, o que há de mais significativo em sua vida: é o que foi vivido mais intensamente, aquilo que merece ou mesmo aquilo que pode ser lembrado.

Geni, Pedro, Arlindo e Joanin, todos têm lembranças do Rio do Ouro e do tempo antigo, ali e nas proximidades. Formam um grupo, uma comunidade que se lembra. Ainda que possivelmente cada um tenha vivido muitas experiências desencontradas ou que não tiveram eco para outras pessoas senão para si mesmos e para os mais próximos, o sentido coletivo de memória permanece. Permanece não apenas por pertencerem a um grupo, partilhando de uma mesma época e um mesmo lugar, e vivendo, cada um a sua maneira, uma série de fenômenos coletivos tiveram significado para uma comunidade inteira, que é, nas palavras de Halbwachs, uma "comunidade afetiva". Permanece também por aquilo que Halbwachs chama de "nunca estar só": cada um deles estava acompanhado de lembranças, idéias e imagens que não são necessariamente suas, mas que foram incorporando ao longo de suas vidas. São pessoas que levamos conosco, sem que se distingam materialmente de nós.

O autor sublinha a importância de que essa comunidade que se lembra continue a reconhecer-se como tal, ou ainda, que essa comunidade não tenha perdido o hábito e o poder de pensar e de se lembrar enquanto membro do grupo, que compartilha de noções comuns. Por isso, para que nossa memória se auxilie com a dos outros, é necessário que ainda existam pontos de contato e de concordância entre essas memórias, para que a lembrança que nos recordam possa ser reconstruída sobre um fundamento comum. Quando a comunidade na qual estávamos acostumados a partilhar torna-se, por algum motivo, estranha a nós, não conseguimos mais reconstituir com eles o grupo antigo, e junto com o grupo, todo o conjunto de lembranças que temos em comum (Halbwachs: 1990). Esse afastamento nem sempre acontece no plano do concreto: podemos não mais compartilhar nossas lembranças com pessoas que continuamos a ver; ou, por outro lado, mantermos aspectos de nossa memória ligados a um grupo com o qual não permanecemos em convívio freqüente. 
Embora estejamos aqui relatando as memórias compartilhadas entre os narradores da Barra do Ouro, na prática eles pouco compartilham suas lembranças. Por quase não saírem de casa, não se encontram com os amigos do tempo antigo. Quando perguntei a Pedro se ele conhecia Seu Joanin, ele respondeu que

Conhecia, nós se criamo junto, perto, desde novo nós se conhecia, desde gurizada. E ele tá ali pertinho e eu não posso visitar ele nem ele vem me visitar aqui

Entrevistando um e outro narrador, o meu ponto de vista era de que se tratavam de memórias compartilhadas, ainda que eles não mais conversassem entre si. Imbuída dessa reflexão e desse sentimento, era inevitável que, em alguns momentos da pesquisa, atuasse como uma mensageira, levando e trazendo as lembranças e as referências que cada um fazia ao outro durante as entrevistas.

\section{Imagens de velhos}

Freqüentemente, aos velhos é atribuído o papel de guardiões da memória de uma comunidade. Eles são muitas vezes aquilo que resta do tempo antigo, num momento em que as modificações sociais, culturais e econômicas acontecem rapidamente. É a figura do ancião, o eixo de uma comunidade, aquele que é capaz de unir passado e presente, de refletir sobre as modificações decorrentes da passagem do tempo e transmití-las aos mais jovens. Esse papel conferido ao velho nos remete novamente à figura do narrador, retomada por Walter Benjamin (1994). Assim como o narrador, o velho tem muito a dizer. Ele reúne o acervo de experiências de toda uma vida, acervo esse que na proximidade da morte precisa ser passado adiante. Benjamin coloca que é no momento da morte que a sabedoria e a existência vivida do homem assumem uma forma verdadeiramente transmissível. Um saber que não refere-se apenas à própria experiência, mas também à experiência alheia, uma vez que o narrador assimila à sua vida aquilo que sabe por ouvir dizer.

As estórias de vida de Dona Geni, Seu Pedro, Seu Arlindo e Joanin são contadas entrelaçando não apenas as estórias daqueles que compartilharam com eles um tempo e um lugar, mas também as estórias que lhes foram passadas pelos antigos. O "ouvi dizer que", 
"tem uma estória que diz", "tinha uns lá no fundo", são expressões que reforçam a idéia de uma memória compartilhada na própria constituição das estórias de vida dessas pessoas, assim como o narrador incorpora fatos externos à sua vida como experiência a ser transmitida na narrativa.

Quando falávamos do incêndio que destruiu a igreja da Barra do Ouro, Seu Pedro resumiu assim a vida de um dos principais personagens da estória:

Ah, que padre era? Era Padre Matias. Padre Matias e tinha o Padre Antônio quando queimaram a igreja então aí o padre Matias ele queria um ajudante, aí veio o padre da pré paróquia e ele ficou de ajudante, o padre velho aí. Daí ele se desgostou, se desgostou e saiu, não quis ficar junto com o outro aqui. Aí ele foi pra Maquine. Depois ele faleceu, escolheu o lugarzinho pra ser enterrado ali perto da igreja. Depois assim como ele foi pra lá, a irmã dele, quando ele faleceu disse: vocês não quiseram ele de antes agora nem de morto vocês vão ter. Mandou enterrar lá. Aquele padre ficou ali mais ou menos...mais de vinte anos na paróquia ali. Foi o padre que levantou, que levantou mais a paróquia foi aquele padre

E Dona Geni refere-se aos costumes de um tempo ainda mais antigo:

Antigamente mesmo mais, antes de mim, essas mulher véia não usava carça. Carcinha. Não usava. Era só vestido e saia. Não botavam carça. Saíam pra passear, vinham na missa, tudo. Não tinha carça"

Benjamin (1994, p.198) distingue dois grupos de narradores: o narrador que vem de longe e traz estórias de outros lugares; e o narrador que permanece em seu lugar, conhecedor de suas estórias e tradições. Enquanto Seu Pedro e Dona Geni se assemelham mais ao narrador que é enraizado em sua cultura e tradição, contando essencialmente as coisas de seu lugar, Seu Arlindo destacava muito nas entrevistas uma imagem de viajante. 
esmo nascido no Rio do Ouro e tendo vivido grande parte em Maquiné, ele se deslocava continuamente em função do trabalho como fotógrafo. Sua imagem era para mim a do viajante que leva estórias e novidades de longe às pequenas comunidades, como aparece em uma passagem de uma de suas conversas comigo:

Eu aqui, comecei a trabalhar eu aqui a zona toda Terra de Areia, ia até Osório, até São Francisco, essa região toda, Santo Antônio eu ia, depois aqui, beira da praia, onde vai pra Capivari, essa zona aqui, fora Terra de Areia, Itati, Bananal, Torres, Sombrio.

Mais adiante, quando interrogado por mim se viajava muito, Seu Arlindo respondeu:

Bah, eu cheguei parar 15 dias fora de casa. Ah, eu andava, eu parece que quando eu passava eu tinha um ímã, os outro me agarrava...eu tinha amor àquilo. Aonde eu ia vinham tudo lá parece que eu tinha um ímã, graça de deus que me ajudou

Esses narradores podem não mais se encontrar uns com os outros para rememorar o tempo antigo, mas ainda assim compartilham uma memória daquilo que viveram. Em contrapartida, em sua convivência diária com pessoas mais jovens (filhos, netos, sobrinhos), talvez eles compartilhem muito pouco de sua experiência. O diálogo entre as gerações é importante na medida em que restitui ao presente hábitos de outrora já esquecidos, criando uma rede de conhecimento paralela à rede de informação rápida e fatual proposta pelos meios de comunicação, à qual as novas gerações estão cada vez mais habituadas. Se não há quem ouça as estórias que estão aí para serem contadas, a figura do narrador, como conclui Benjamin (1994, p.197), encontra-se mesmo em extinção. Desaparece a comunidade de ouvintes, desaparece a comunidade de narradores. Os narradores existem até que haja eco para suas estórias, até que haja ouvidos para 
aprenderem com ele os ensinamentos e as palavras de sua sabedoria. "Contar histórias sempre foi a arte de contá-las de novo, e ela se perde quando as histórias não são mais conservadas" (1994, p.205).

É assim que o papel de um guardião da memória pode ser um tanto inerte e estanque, se não for incitado a transmitir sua experiência. colocado à margem dos acontecimentos presentes. Como em um museu, onde as peças estáticas ilustram um tempo passado, sem, no entanto, desafiar o presente. Rejeitar o velho por suas limitações físicas, pela perda da força de trabalho, ou pela falta de coerência e de linearidade na fala é uma forma de manter o passado à uma distância segura, que se mostra incapaz de modificar ou refletir sobre o curso do presente. Ao velho não cabe mais um papel ativo na história social: ele é velho, já viveu e hoje rememora, apenas.

Ecléa Bosi, no livro em que fala sobre a lembrança de velhos no contexto paulistano, reforça que "não se discute com o velho, não se confrontam opiniões com as dele, negando-lhe a oportunidade de desenvolver o que só se permite aos amigos: a alteridade, a contradição, o afrontamento e mesmo o conflito.” (1994, p.78). Como veremos mais adiante, nem sempre o velho permanece à parte das situações de conflito: muitas vezes elas são desencadeadas por sua presença no núcleo familiar.O conflito entre gerações esmorece na medida em que o velho é tomado apenas como aquele que lembra, e principalmente, na medida em que diminuem os ouvintes dispostos a escutá-lo. O ouvinte não é necessariamente aquele que escuta impassível, sem esboçar reação ou discordância. Muitas vezes é o ouvinte que leva o narrador a repensar sua história, refletir suas escolhas, e recontá-las de forma diferente. É a curiosidade e a inquietação de quem escuta que confere atemporalidade e continuidade ao ato de narrar. De forma análoga, a memória pode permanecer intacta se não for desafiada pelo presente. Opôr as imagens do presente e do passado significa dar a elas um novo sentido, um novo olhar. No caso do velho, esse confronto entre passado e presente exige um discernimento daquilo que é lembrança do que é a vida atual, em uma observação lúcida das mudanças. 
Conforme me relatou Seu Arlindo,

Eu posso dizer que qualquer um de nós, por exemplo, nem que tu não queira, te deu qualquer um furinho no corpo, uma doença, nunca mais tu é aquela pessoa, nunca mais. Tem dias que tu tá com o cérebro que tu te lembra tudo de que tu tinha 5, 6 anos, e tem dias que tu quer te lembrar o nome dum filho tu não te lembra mais

Na ocasião da velhice, aumenta o número de imagens dos tempos antigos. O velho, que já não se ocupa mais das tarefas cotidianas como o trabalho e o sustento, naturalmente é levado à rememoração. Para Bosi (1994:60), "ele está ocupado consciente e atentamente do próprio passado, da substância mesma de sua vida”. Esse lembrar-se é também um ato de revisão de vida, de aceitação daquilo que se foi capaz de fazer.

Em uma de nossas conversas, Seu Pedro sintetizou assim sua vida:

E passei trabalho na minha vida, passei trabalho. Colocar meus filho, queriam casar, eu terra não podia dar pra eles, então dava casa, casavam, dava casa, colocava aqui, colocava lá, não dá aqui, não dá, eles iam pra cidade. Saíam dali iam pra cidade. Passei muito trabalho. Ainda ontem tava falando aqui da minha bisavó, ela faleceu com 105 ou 110 anos, não me lembro bem. Então aquele sobrinho que ta ali tava dizendo: tu vai puxar pro lado da tua bisavó

Ao mesmo tempo em que fala do passado, o velho está permanentemente construindo a trajetória de sua vida, selecionando aquilo que vale ou não a pena contar, ou seja aquilo que, na memória, faz ou não parte de sua história de vida. Contar apenas as coisas boas ou gloriosas, sejam da vida ou da própria personalidade, é uma forma de deixar pra trás aspectos menos desejosos, deixando-os do lado de fora da construção narrativa acerca de suas vidas. Nas entrevistas, foi comum a todos os entrevistados a retificação da importância de seus papéis para a família e para a comunidade. Dona Geni, por exemplo, se apresenta para mim como uma mulher forte e admirada na comunidade. Lembrando a época em que era dona de uma pensão na Barra do Ouro, ela acrescenta:

olha, tu sabe que eu tinha uma destreza que todo mundo não acreditava que eu...tinha domingo que eu atendia 50 pessoas

Em outro momento da conversa, explicando como trabalhava no fogão à lenha, Dona Geni complementa: 
Eu amassava pão antes de me deitar! Madrugada eu me levantava amassava pão e me deitava de novo. Quando era de manhã tava dando café com pão quente. E as mulher aí da praça comprando pra tomar café.

Da mesma forma, a fala de Seu Arlindo retrata sua habilidade como fotógrafo:

Num sábado eu fiz um casamento e a primeira comunhão, domingo: 1312 postais a cores, eu tirei num dia, até meio dia, né, posso dizer que eu gravei que tenho 1312 poses. Não falhou uma. Que o negócio de bater tem gente que diz 'eu bati 12 mas queimou 10, bati 5 só saiu 3, queimou', só aquela maldita ladainha de ver dizer bati tanto, mas tanto queimou.

Os feitos de nossos avós são grandiosos: o relato de suas vidas sempre nos impressiona. É comum escutarmos nos relatos dos mais velhos uma exaltação da vida no tempo antigo, especialmente quando comparada com o tempo presente. Essa exaltação refere-se a sua própria vida, a um reconhecimento que merece receber pelo tempo vivido. A valorização de suas vidas no tempo antigo vem muitas vezes acompanhada de uma crítica às modificações do presente e à uma quebra, por parte dos mais jovens, da continuidade de um modo de vida. Como relata Dona Geni,

No verão a gente ia, sentar lá dentro do rio, assim, mas de roupa, né, de roupa a gente ia. Com uma saia, uma brusa. Agora não, vão tudo nú, né? Tudo nú, aqui vai tudo nú. Pensa que botam roupa? Tudo nua, se vão num lugar quando vai arguém de homem junto, tem as carcinha, mas quê que adianta?

Ou como desabafa Seu Arlindo:

Não sei, parece que a rapaziada de hoje não quer aprender nada. Não desfazer alguém que estuda, assim...Eu até tentei muito pra ver se eu conseguia uma pessoa, tu ver eu trabalhar 52 nessa região, desde que eu me formei fotógrafo, e não consegui um que interessasse a aprender pra ficar um

Todos os entrevistados eram referenciados pela comunidade como "aqueles que sabiam" ou que "tinham histórias do tempo antigo para contar". Por serem os mais velhos ou por terem desempenhado importantes papéis na comunidade, eram referências da história da Barra do Ouro e já haviam sido entrevistados em pesquisas sobre a história 
local. No entanto a maior parte desses entrevistadores eram pessoas de fora, "estrangeiros", que como eu, viam algo de especial na história do lugar. Algumas das pessoas mais jovens que me indicaram os narradores não haviam sequer conhecido-os pessoalmente, fato que, em uma comunidade pequena, retrata uma ambigüidade no tratamento e no valor que é dado ao velho, e com ele, ao passado. Uma professora da escola, moradora da Barra do Ouro, indicou para minha pesquisa o nome de Seu Joanin, dizendo que o admirava pela idade alcançada e que sempre teve curiosidade sobre o fato dele mascar fumo, mas que nunca havia perguntado a ele. A resposta foi dada a ela por mim: em nossa conversa, Seu Joanin contou que aos quatorze anos de idade sentiu uma dor de dente muito forte e, imaginando que o fumo pudesse resolver, mascou até que a dor passasse; se essa de fato passou, o hábito persiste até hoje, 83 anos depois. Contada por mim, essa história teve na comunidade a tradução de uma estrangeira, que escuta o passado e atribui a ele um valor que nem sempre é dado pelas pessoas do lugar. Novamente aqui, enquanto pesquisadora em campo, me colocava no papel do mediador cultural (Velho, 2001), comunicando estórias de um mesmo lugar entre seus moradores.

No caso dos entrevistados, o sentimento de ambigüidade em relação ao velho estava presente no papel que lhes era comumente atribuído em suas casas: se por um lado centraliza as atenções pelos cuidados que lhe são reservados, por outro é esquecido dada a dificuldade de participar das atividades cotidianas. Além dos empecilhos concretos para a participação do velho na família, existem os simbólicos: o passado nem sempre é bemvindo no momento presente.

Myriam Lins de Barros (1987, p.79) afirma que a escolha do lugar que o velho ocupa dentro do grupo doméstico refere-se ao fato de ele se perceber como elemento central ou periférico na família. Dona Geni e Seu Joanin vivem sozinhos, vizinhos às casas de seus filhos e noras; Pedro e Arlindo vivem, respectivamente, com o filho e a nora, e com a filha, ambos os mais novos e que ficaram com a responsabilidade de cuidar dos pais. $\mathrm{Na}$ fala dos entrevistados, pouco aparecia do sentimento de mágoa por serem muitas vezes relegados ao segundo plano na família; quando aparecia era nas entrelinhas da conversa, e 
em momentos mais informais, com o gravador desligado. Mas a relação de conflito e dependência entre o idoso e os familiares estava expressa na situação da entrevista: com exceção de Dona Geni, a conversa com os entrevistados contava com a presença dos familiares, que se colocavam no papel de mediadores, consertando as possíveis falhas de memória dos pais/sogros. Algumas vezes esse "conserto" chegava a situações de conflito, onde apareciam divergências sobre episódios relatados

Barros (1987, p.109) compara a questão do núcleo familiar com uma arena, que é cruzada em diversos níveis por uma heterogeneidade de interpretações de sua realidade. O conflito que ocorre da divergência de opiniões não é necessariamente destruidor de uma unidade social, a família, ao contrário, vem à tona justamente pelo caráter afetivo dessas relações.

Durante as entrevistas com Seu Arlindo, sua memória estava em constante negociação com a de sua filha. Ela o corrigia, dizia que ele não estava contando o certo e que misturava realidade com ficção. De fato, Seu Arlindo apresentava sinais da doença de Parkinson há dois anos, e tinha dificuldade em se lembrar de nomes, datas e acontecimentos. Mas isso não era relevante em minha pesquisa; era a memória que ele havia construído acerca de sua vida que interessava, independente de ser ou não condizente com o que de fato havia acontecido. Enquanto pesquisadora, eu sentia que estava invadindo um terreno o qual não pertencia, provocando uma situação de conflito que talvez não viesse à tona se não fosse a minha presença.

Esse conflito geracional acerca da reconstituição do passado nos traz a idéia de uma memória negociada, onde entre aqueles que compartilham lembranças comuns, como o caso de familiares, nem sempre a lembrança em torno de um mesmo acontecimento é comum. E nem sempre a idéia do que deve ou não ser lembrado é compartilhada.

\section{As imagens da memória}

\section{Imagens do Rio do Ouro}

Ouvindo os relatos de moradores da Barra do Ouro sobre a vida no tempo antigo, em algum momento, evocam-se imagens da linha do Rio do Ouro. Seja por terem nascido ou 
vivido lá, participado de festas ou ouvido falar das estórias do lugar, o Rio do Ouro é sempre sinônimo de um tempo passado, e de tudo o que o passado da região é capaz de evocar.

Grande parte dos imigrantes que chegaram à então Colônia Marquês do Herval se estabeleceram no Rio do Ouro. Apesar de ser uma linha extensa em sua profundidade, com muitos moradores no fundo do vale, tinha uma posição estratégica junto ao núcleo urbano da Barra do Ouro e às estradas que faziam a ligação com os municípios de Taquara e São Francisco de Paula. O modo de vida era outro, as distâncias eram outras.

Os informantes dessa pesquisa viveram no Rio do Ouro em diferentes momentos da vida, e cada um guarda estórias que falam de sua relação com o lugar, mas todos compartilhando de um mesmo modo de viver que caracterizava a linha. A partir de seus relatos, imaginamos uma localidade cuja vida social se fazia intensa. Festas na capela, aniversários, casamentos, caçadas, plantios e colheitas, além do trabalho diário na colônia, remontam a um tempo que parece só existir no imaginário daqueles que escutam. Ouvindo as lembranças desses narradores, a imagem de um Rio do Ouro parece se reconstituir em nossa mente.

F: Tinha moinho?

G: Tinha, fazia farinha. Lá no Rio do Ouro inha um, que era da minha sogra, primeira sogra, né, e tem esse daqui de cima, que moía trigo, e milho também. E feijão, nós óia, o último ano que nós paremo no rio do ouro, que nós colhemo feijão, vendemo cento e dez saca de feijão! Nós prantava lá nos morro lá, eu não ia né, eu ia só tempo da colheita, eu sempre tinha minha lavoura perto de casa. Que eu não acompanhava ele assim longe, por causa das criança, né, então eu trabaiava perto, tinha uma lavoura grande perto de casa então eu prantava ali, batata, aipim, miudeza assim pra casa, né, e ficava em casa, fazia comida, e cuidava da criação, sempre tinha muita criação, muita galinha, muito porco, a gente sempre tinha bastante coisa, né, então não ia eu ia só o tempo que se colhia feijão. Porque aí nós não batia a pau como essa gente agora faz, né, criava com os animal. Enchia a eira de feijão e subia com os animal pra cima e

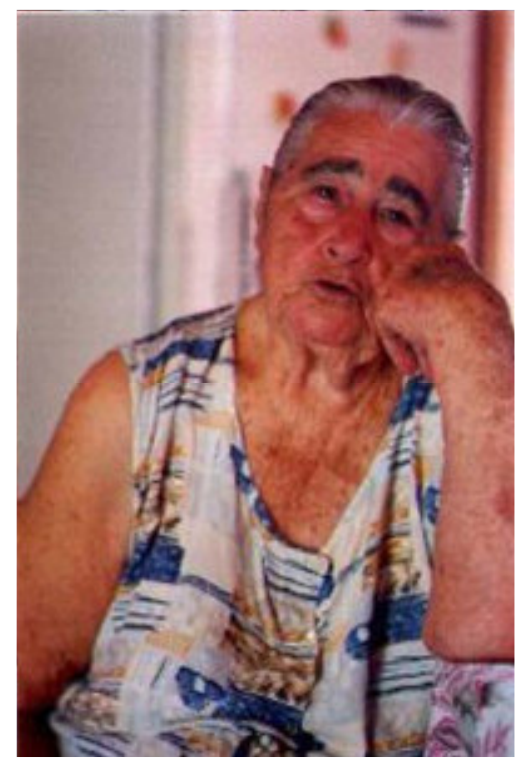
galopeava ali, troteava em cima do feijão, os animal que batiam o feijão. Nós batia dez saco por dia, nós dois. Ele ia bem cedo e eu ficava, ficava e catava a criação, os porco, as galinha, e fazia armava as coisa pra levar pra comer lá em cima na roça, as panela, o cargueiro e arrumava as criança e botava no cargueiro e subia, onde é que ele tava. 


\section{F: Como era o cargueiro, era de boi?}

G: Não era de cavalo. Botava dois cesto, um cada

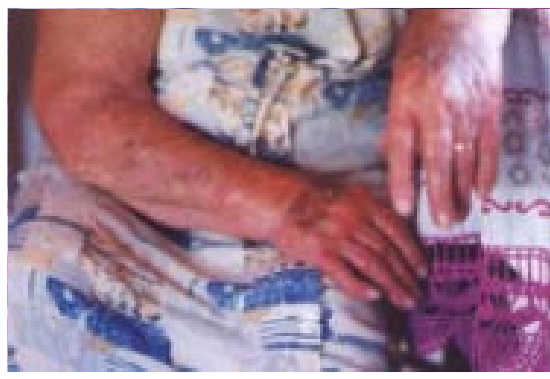
lado, né, as criança dentro, e a comida, eu levava a comida pra fazer lá, fazia na roça a comida em tempo de colheita de feijão. Milho eu nunca fui ajudar a quebrar, milho eu ficava em casa, ele ia quebrar o milho e a tropa trazia, uns quantos animal trazia,

descarregava em casa e eu fazia as pilha. Nós fazia tudo empilhado dentro do paiol. Fazia até no forro. Enquanto eu alcançava pra botar o milho assim eu fazia a pilha. Até que eles vinham com outra carga, eu já tinha juntado aquela carga e já tinha empilhado.

F: E secava o milho ali?

G: Já vem seco da roça, né! Ali a gente descascava pros porco, pra ir no moinho, descascava pra vender, né, pra debuiá, quando era tempo de vender a gente descascava, botava pra dentro de casa com a máquina a gente moía, debuiava ele com a máquina, não com as mão. Tinha máquina de debuiá milho, fazia, se ajuntava os vizinho, uma noite numa casa outra noite noutra a gente debuiava o milho, né. Nós dançava, nós cantava, nós pulava, nós fazia coisa pra comer, e debuiando o milho. Ia um tocando a máquina e outro botando as espiga e outro tirando o sabugo. Que vai caindo da máquina que debuia o milho. Nós tinha tudo! Nós não debuiava milho em mão. Tudo com a máquina.

P: Dava seca, então a farinha de milho a gente moia nos moinho que trabalhavam aqui, e pra lá era seca, não moia. Então nós levava farinha pra lá, vendia tudo lá. Era um lugar muito perseguido de seca. Aqui sempre tinha, tinha um moinho aqui que era ali no Rio do Ouro, nunca parava aquele moinho, podia ser seca, sempre sempre trabalhou aquele moinho. Noutros lugar parava mas ali, aquele não parava.

P: Ali tinha a sociedade das capelinha, era trinta família de, como diz... de sócio. Trinta pessoa de sócio entrava. E ali já tinha pra sessenta! E depois onde é que foram essas família tudo? Tudo saíram, foram pra cidade. O que não morreu, saiu.

F: Aonde isso?

P: A sociedade das capelinha. F: No Rio do Ouro?

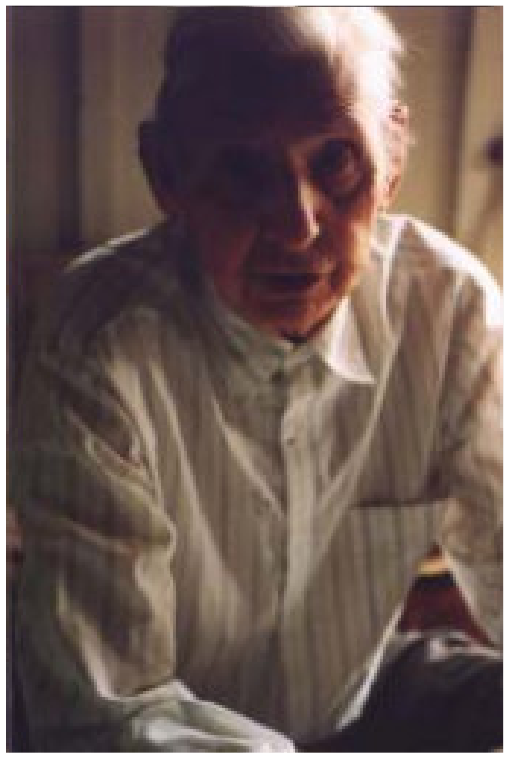

P: É, era no Rio do Ouro, por tudo ali tinha as capelinha.

Trinta família já formava uma capelinha. Hoje tem as capelinha, tem, mas o povo já ...fazem a capelinha, já entrega e ...uma vez não, uma vez a gente acompanhava a capelinha dum vizinho pra outro. Fundo do Rio do Ouro, aquelas linhas toda que tu conhece lá eu fotografei tudo o que tinha ali de importante. Porco gordo, porco magro, gado... bom, quati mondeo, bugio, macaco, esses coisa diferente, moderno, morto, vivo, pegado pra criado na jaula, não tinha o que... cobra, cobra grande, comprida, depois de morta, viva também. Bom, eu tenho que pensar muito pra lembrar mesmo tudo o que eu fotografei. 


\section{Imagens do presente}

A cada entrevista, a cada fala e cada suspiro do narrador, ali estava uma imagem. Eram imagens do passado, de uma vida e um lugar que já não são mais como outrora. Eram imagens do presente, da vida que hoje se faz possível. E eram sobretudo, imagens de como passado e presente se enxergam, se confrontam e se complementam.

Quando fui ao Rio do Ouro fazer as fotografias estava acompanhada apenas dos relatos desses velhos narradores, que ali haviam vivido parte de suas vidas. As imagens que fiz também estavam dentro dos limites do presente: não havia mais os grandes parreirais, a roça no morro, os fornos de barro, os moinhos, os cargueiros, as famílias andando na estrada, a louça lavada no rio. O cenário havia mudado, mas ali ainda estavam os rastros de um tempo passado que assim sobrevive, mais envelhecendo do que sendo substituído pelo novo.

O Rio do Ouro é uma linha que foi abandonada, e que assim permanece. São poucos os novos moradores e as novas construções. Encontrei muitas casas velhas e sem moradores, degraus de concreto que ali ficaram a despeito da demolição da casa, o mato crescendo onde antes era roça. No caminho, ninguém cruzava.

Acompanhavam-me também Halbwachs e seus dizeres de que, no momento em que o presente toma lugar dentro do quadro de nossas lembranças antigas, essas se adaptam ao conjunto de nossas percepções atuais. Como o confronto de vários depoimentos que apesar de algumas divergências, concordam no essencial, e é por isso que podemos reconstruir um conjunto de lembranças de modo a reconhecê-las (1990).

Dona Geni e Seu Arlindo há muito não iam ao Rio do Ouro. Sobre as mudanças que ali tinham tomado forma, imaginavam apenas. Seu Pedro ainda ia com frequiência. Lá mantinha uma casa onde costumava passar o dia com o filho e a nora.

Mostrar as imagens do presente era uma forma de levar aos entrevistados um outro Rio do Ouro, que eles talvez não conhecessem, não apenas pelas mudanças que se fizeram ao longo dos anos, mas também por se tratar de um outro olhar, um olhar "de fora", “estrangeiro" e que eles nunca tiveram. Era propor uma nova imagem na memória de cada um. E restituir antigas imagens no confronto com as novas. 


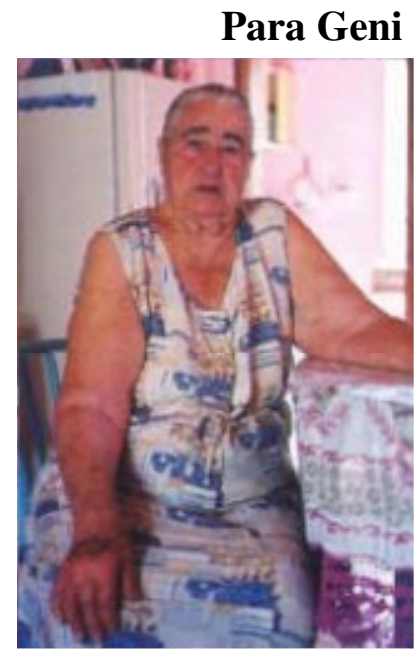

Dona Geni ia segurando as fotos uma a uma, na mesma mão, como se fossem cartas de baralho. Ela estava atenta às imagens e observava cada uma separadamente, num sincero esforço para compreendê-las. Foi o momento de troca mais importante em minha relação com essa informante: na medida em que eu havia mostrado meu envolvimento nas estórias de sua vida ao produzir as imagens, ela também se envolvia no meu trabalho, correspondendo à minha expectativa no sentido de contribuir, com aquelas imagens, à seu processo de rememoração.

Num primeiro momento, mostrei os retratos que havia feito dela, em nossa última conversa. Dona Geni se impressionou com a quantidade de fotografias. Eram oito imagens, a maioria com ângulos fechados, em que Dona Geni aparecia gesticulando, contando histórias, conversando comigo. Com o equipamento que tinha e na distância em que estávamos uma da outra, as fotografias mostravam Dona Geni ocupando quase que todo o quadro. Não queria me distanciar muito dela nem chamar atenção para o fato de estar fotografando, minha intenção era de seguir sendo sua ouvinte, mesmo que a câmera, nos momento em que fotografava, ocultasse meu olhar.

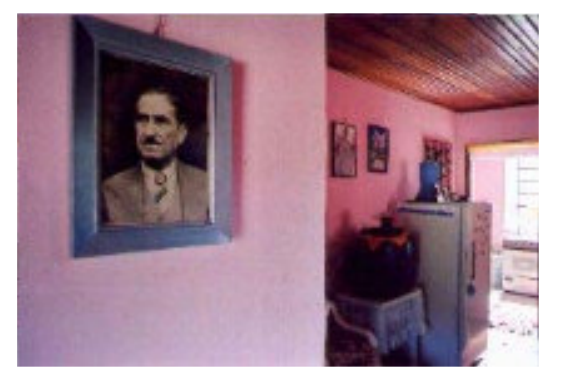

F: Esses são os retratos que eu fiz da senhora

G: Mas tudo isso de montão ela fez! Nossa! Ah, mas tô muito feia aqui (...) o rosto muito grande, né. Óia aqui já tá melhor. Eu não tenho... tem pessoas que tem energia de tirar foto, né, eu não.

F: De ficar bonita na foto?

G: É, a-hã, tem pessoa que fica, tem essa minha neta ali fica tão bonitinha...ué, meu pai! Pois é meu pai tá igualzinho ali.

F: Igualzinho que nem ele era

G: Claro, e ali ele, tá ali. Igualzinho. Eu fiquei assim (mostra com a boca)

F: Falando?

G: Ah, eu tava falando quando tu bateu, né. Aqui fiquei só com as mão?

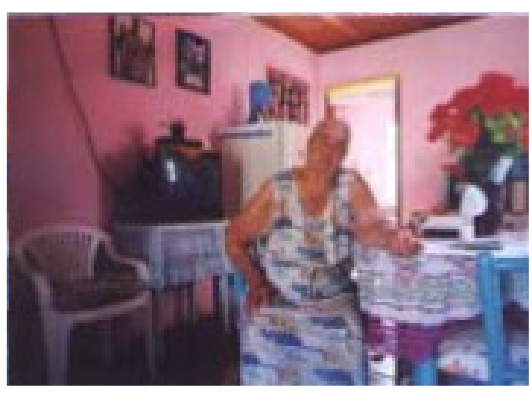

F: Hum-hum

G: O que que eu tava fazendo que te mostrei?

F: Tava dizendo alguma coisa aqui com a mão que tapou o rosto!

G:pois é. eu tava fazendo isso assim, né. naquele lá tô mais miúda, né? ah, sabe porque que ficou grande? porque tu tirou perto, né. tirasse mais longe ficava mais pequena.

F: Essa daqui que a senhora falou que tá melhor, né, que tá menor...

G: E eu tava gorda, né. Os bração ainda tava cheio. É... Eu ando viajando contigo.

F: Viajando?

G: É. Aonde tu vai tu leva, né. E meu pai também. 
Dona Geni possuía poucos retratos seus. Quando na última visita perguntei se ela tinha alguma fotografia sua, apontou para um porta-retrato em cima da geladeira, que uma menina aos 17 anos, vestida de branco e com um ramo de flores em uma das mãos. Lembrou que havia outras, de quando fez 80 anos e a amiga de sua bisneta levou uma máquina fotográfica.
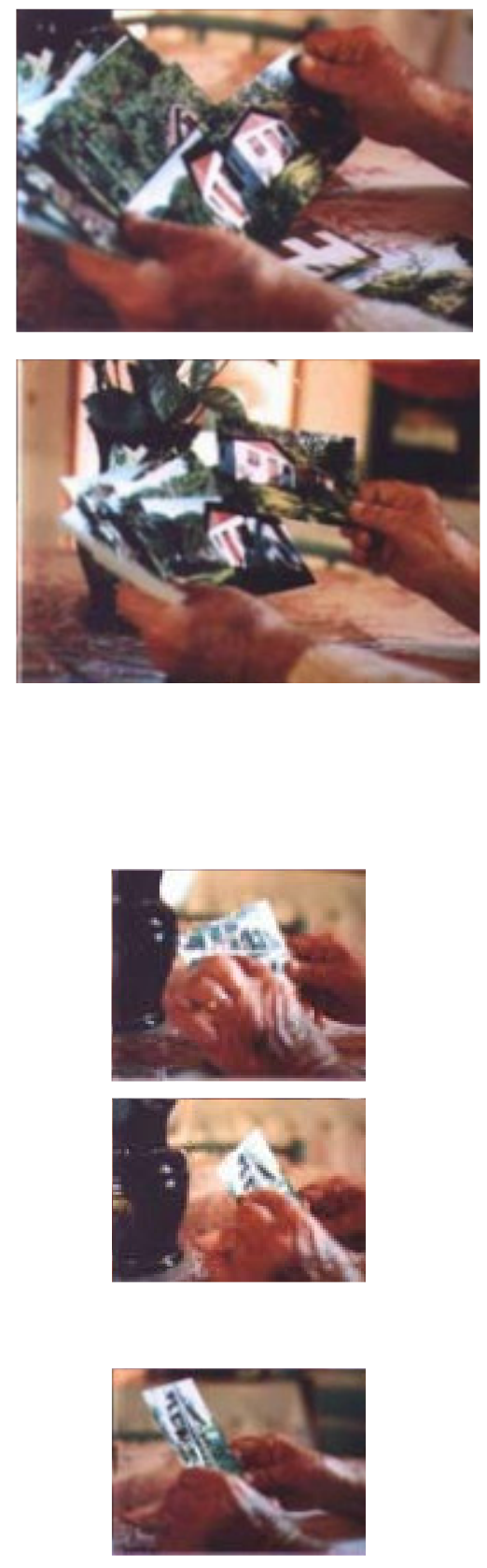

F: Essa a senhora não lembra?

G: Essa eu não me lembro. Agora se eu fosse lá daí eu te mostrava tudo, né, que daí eu indo lá eu sabia de tudo aonde que morava, né.

\section{F: Essa é a igreja, Dona Geni}

G: Essa aqui

F: A igreja e o salão paroquial, bem do lado do cemitério. Tem o cemitério aqui em seguida, ó, ele tá aqui no fundo, logo aqui tá a igreja...

G: Aaaah, tá. Pois aí eu tava achando esta aqui. E essa aqui é uma casa perto da igreja, né? $\mathrm{E}$ tu sabe de quem? Da gente da...dessa aqui que mora ali perto da igreja, como é, a Verônica, a casa dos pais dela, aqui, essa aqui, que ela morava perto, né...(vê outro ângulo da igreja) Pois aqui que eu ia te dizer que era a igreja, que essa ficou bem a vista.

F: E essa aqui Dona Geni?

G: Pois é, essa daqui eu botei práli, porque isto aqui é uma passagem onde que tu passou. Será que não é o rio?

F: Ela ta virada, né?

G: Ah, ela é de pé? Então aqui é uma árvore, um palanque, né. Aqui é uma cerca. Aqui é uma escadaria de...de madeira, porque sobe aqui degrau, né. 


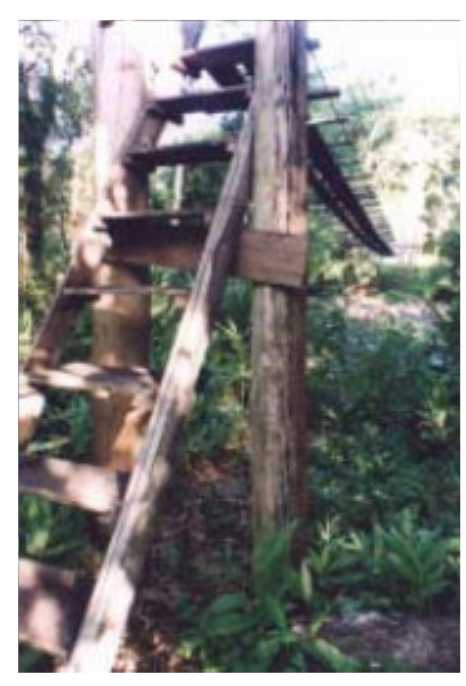

F: É as pinguelas, né, o rio ta passando aqui ó. E no seu tempo tinha ponte assim pra passar o rio quando o rio subia muito?

G: Não. Quando era muito cheio que nós saía com animal, que lá nós vinha sempre pra cá de a cavalo, né, nós não podia passar, então se a gente precisava muito vim na Barra nós vinha por dentro, terminava todos rio nós subia aquela lomba, aquele morro que tem ali naquela oficina ali, nós saía ali, de a pé pra vim na Barra. Daí passava aquela ponte que tem ali, aquela nós passava pra vim pra cá, comprar as coisa.

Ao final de nossa conversa, Dona Geni se levantou e voltou com um pequeno envelope de papel. Abriu-o e me mostrou seu conteúdo: fotografias de família, em que aparecia abraçando uma irmã, com o filho e a nora em frente à igreja. Para mim, o fato de ela ter mostrado essas fotografias foi um sinal de confiança e troca. Desde o nosso primeiro encontro ela sabia do meu interesse pela imagem fotográfica, mas só agora abria o envelope.

\section{Para Pedro}

Seu Pedro olhou rapidamente uma ou duas fotos e se desculpou dizendo que não enxergava. Sua nora me explicou que ele tinha catarata, algumas coisas ele até enxergava bem, mas as fotografias para ele eram "tudo escuro". "Ele enxerga a hora no relógio que é muito menor, né. Eu acho que ele fica com a vista muito atrapalhada”.

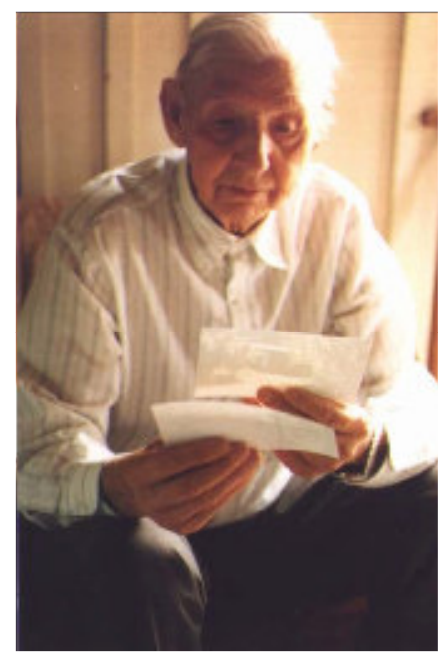

É ruim quando a gente fica curto de vista, né. Tudo é ruim, mas a vista é o pior. Vocês (para o filho e a nora) podem conhecer aí os lugar...Tão conhecendo alguma coisa? 
Pedro ficou sentado à nossa frente enquanto o filho, a nora e o bisneto olhavam as fotografias. Ora alheio e com o olhar distante, ora atento às reações que identificavam as imagens como sendo "ali", "mais pra cima", "passando a igreja assim".

Todos viveram no Rio do Ouro até 9 anos atrás, quando Pedro adoeceu e vieram então para a Barra do Ouro. A casa de Pedro foi referência nos relatos de Dona Geni e Seu Arlindo, que apontaram duas diferentes fotografias de construções antigas como

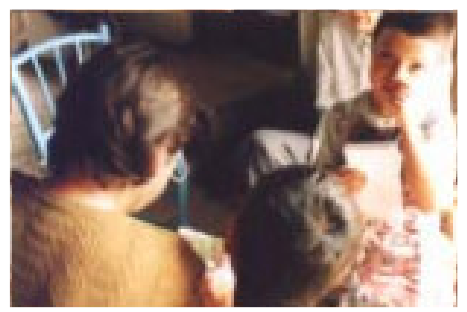
sendo a casa em que Pedro morava. Nenhuma das duas era de fato: sua casa fica no início da linha, mas em cima do morro, e não se pode vê-la da estrada.
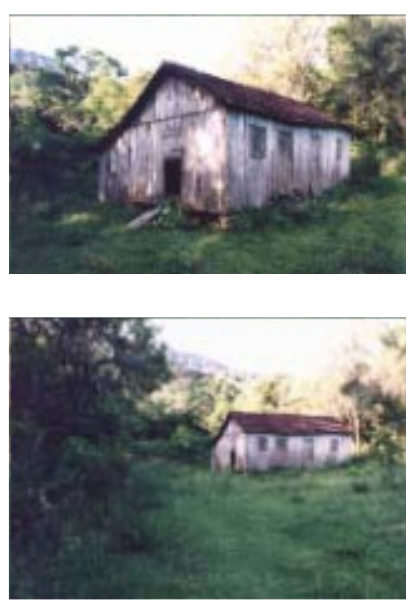

Nora: É que o Arlindo ia lá em casa, mas ele não conheceu a casa, e naquela época que o Arlindo ia era bem diferente, não tinha nem...era de vidro, de veneziana, né pai, nossa casa lá.

Filho: Qual é o Arlindo?

Nora: Adamatti. Não é nem parecida com aquela ali, tinha uma área grande na frente

Filho: Isso. Era bem maior.

Nora: A casa da Zeca ali ele disse que era nossa. Não era nem parecida. A nossa casa era bem grande com uma área grande, e janela de vidro e veneziana. As veneziana são até essas que tão aqui nessa casa, que nós tiremo.

Filho: É as mesma.

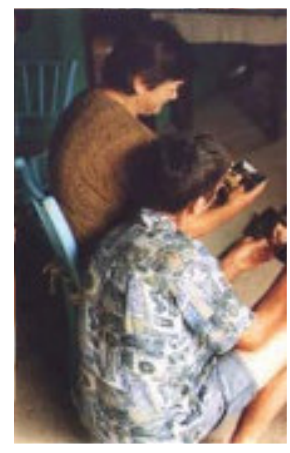

Seu Pedro não podia ver as imagens, mas estava atento às reações do filho e da nora. Em dado momento manuseou novamente uma fotografia e disse: 


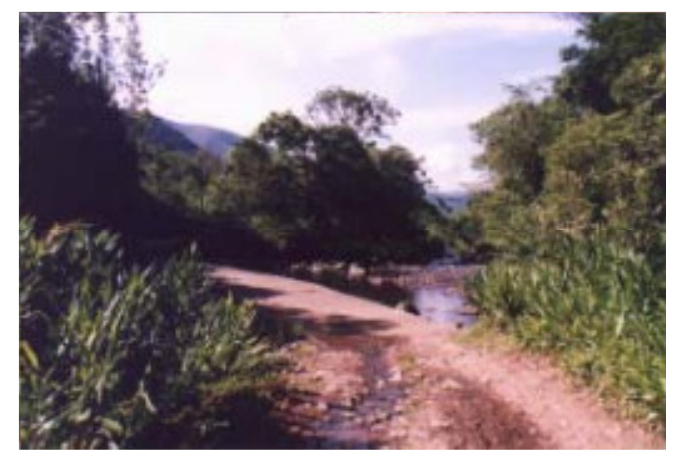

Tá de mudando tudo, tudo de mudando. A gente vai lá agora ta tudo, tudo diferente, faz 7,8 anos que nós tamo morando aqui. Depois aí eu adoeci e fiquei sempre, ficamo melhor aqui. Minha doença vai pra oito anos já. Foi bom que a gente saiu de lá, porque depois se eu adoecia lá como é que ia a gente sair de lá pra ir no médico? Ela (a nora) morava lá bem no fundo do Rio do Ouro. Sabe contar alguma coisa também, né.

Nora: E a estradinha era assim, ó, meu pai só vendia assim tudo de cavalo, os feijão...até feijão nós vendia, não tinha outra coisa (...) Uma outra coisa que a gente vendia, uma vez assim, poucos anos que nós vendemo, flor de pireto. É uma florzinha branca assim, miolinho amarelinho, dizem que era veneno que se fazia da florzinha, veneno de mosquito, de não sei o quê. Nem conseguia vender na Barra, tinha que levar lá pro lado da Pedra Branca, Riozinho, praqueles lado lá.

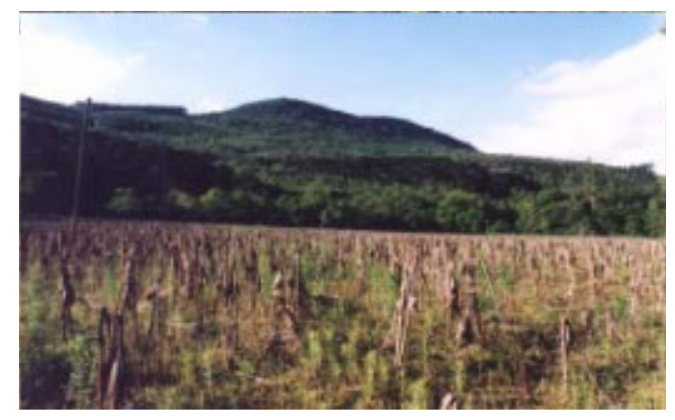
Rio do Ouro?

: Faz tempo que o senhor não vai para o

P: Já faz, faz. Não faz muito.

Nora: Nããão, faz uns 15 dias que nós fomo lá!...

P: Quando eles saem eu tenho que ir junto, porque eu não posso ficar sozinho

Nora: Aí ele tava bom nós fomo de manhã e voltamo de tarde, mas ás vezes nós até dormimo lá, quando ele tá bem bom mesmo a gente fica lá, dorme lá e tudo.

F: Tem tudo, dá pra dormir lá...

P: Tem tudo. Eles vão trabaiá e eu fico lá, em casa. Aqui eu não posso ficar sozinho. 
F: E quando o senhor vai pra lá o senhor acha que mudou muito?

P: Ih, mudou muito, tudo agora, não tem morador, tudo em mato...

F: Tinha mais casa?

P: É, mais casa. Tem poucos morador. Era

família ali e agora ficou lá 3, 4 família só.

É, mudando tudo.
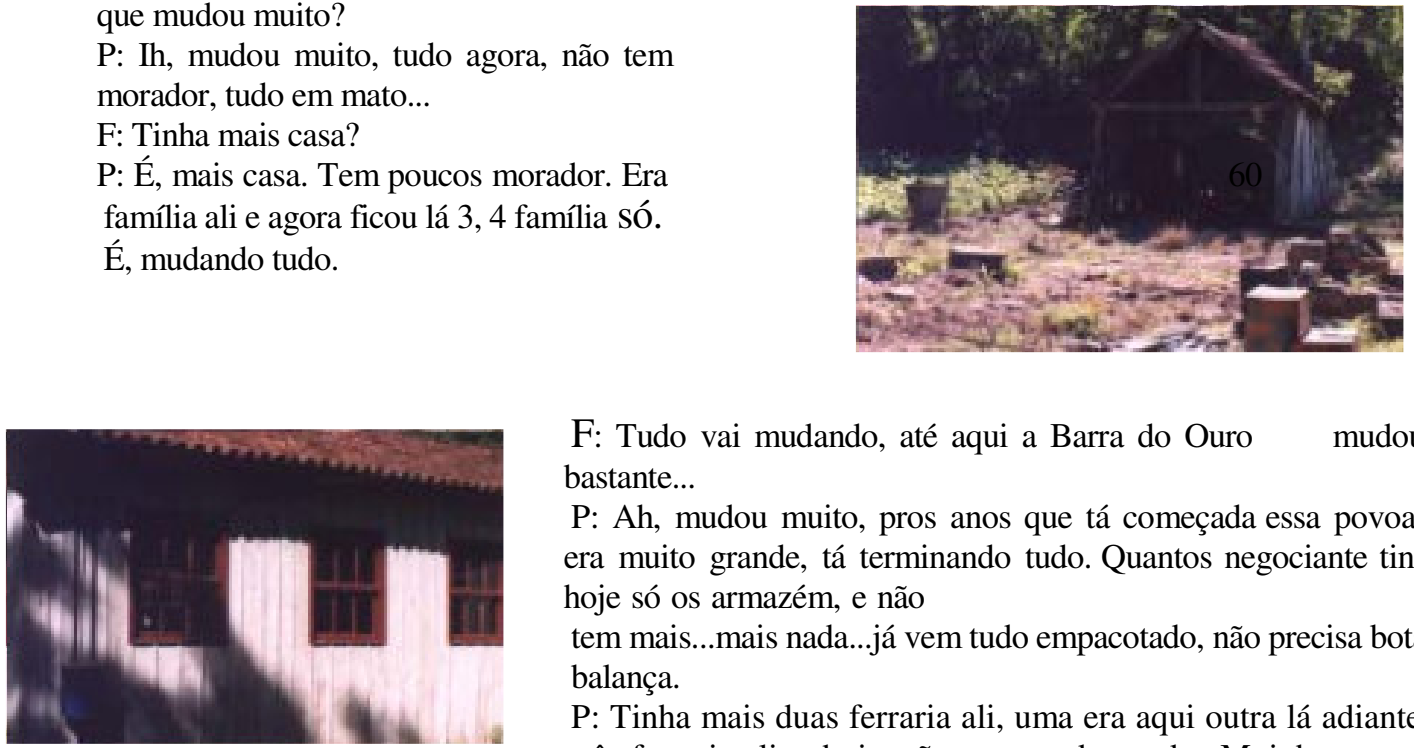

F: Tudo vai mudando, até aqui a Barra do Ouro mudou bastante...

P: Ah, mudou muito, pros anos que tá começada essa povoação ali era muito grande, tá terminando tudo. Quantos negociante tinha aí e hoje só os armazém, e não

tem mais...mais nada...já vem tudo empacotado, não precisa botar na balança.

P: Tinha mais duas ferraria ali, uma era aqui outra lá adiante, tinha três ferraria ali, e hoje não tem nada, nada. Moinho tem só um lá adiante. Mudando tudo. O pessoal foi saindo, não dava de trabalhar na lavoura, foram indo pra cidade e agora, apertou na cidade, né?

Ainda que Seu Pedro não tenha visto em cada foto imagens do Rio do Ouro de hoje, apenas o fato de eu tê-las levado e de seus familiares terem visto e se recordado do tempo em que viveram lá foi motivo para ele contar mais algumas coisas, e principalmente, de colocar o filho e a nora, também como " antigos" para falarem do passado.

\section{Para Arlindo}

Tirei minha câmera da mochila e mostrei para Seu Arlindo. Ele ficou feliz em vê-la, segurou-a com cuidado, examinou-a e falou com euforia sobre os diferentes tipos e marcas de máquinas fotográficas. Nossa conversa tinha muitas vezes o tom de aconselhamento: eu, uma fotógrafa aprendiz, ele um fotógrafo experiente.

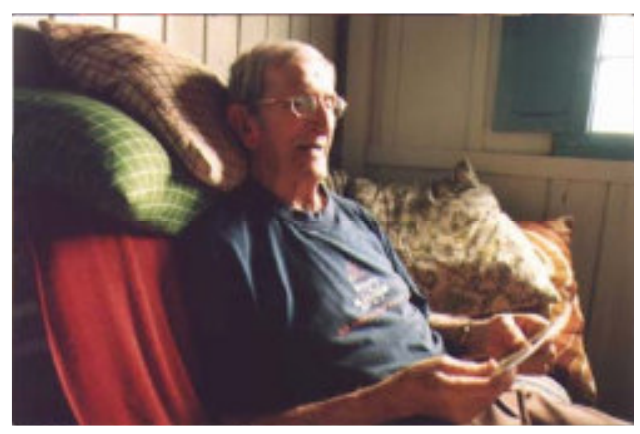


Soube nesse dia que Seu Arlindo também havia nascido e vivido até a idade adulta no Rio do Ouro; na outra entrevista, ele mencionara apenas a localidade de Maquiné. Logo que mostrei as fotos, Seu Arlindo me falou que estavam boas:

A: Tá boa as foto, tá bem tirada. Tudo sol. Mas uma máquina, a máquina ta boa. Era essa mesmo?

F: Era.Ficaram muito claras, né?

A:É, aqui eu acho que...aqui tu tirou, eu sempre olhava a abertura, por exemplo, se dá menos luz, mais luz, sabe o diafragma? fecha o diafragma...mas se tu trabalha na rua não usa flash nunca então tem regulagem dentro da abertura do diafragma, abrir, fechar...Eu tava olhando isso aqui não cheguei a ver...ah, isso

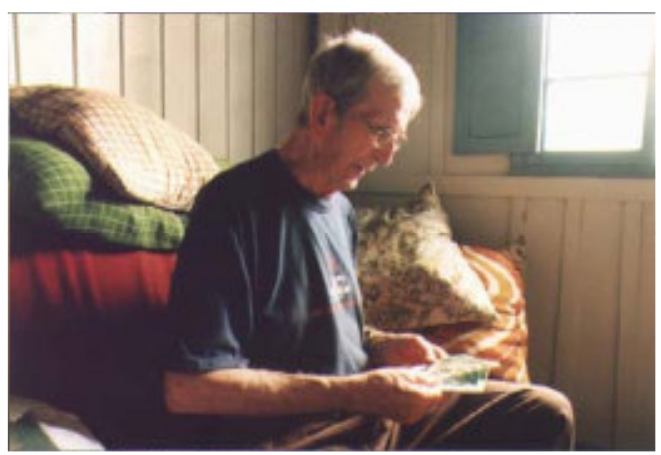
aqui é uma pinguela! Agora não me lembro...é feita, isso aqui é uma árvore que eles colocara uma árvore aqui pra passar.

F: Quando o senhor morava lá tinha pinguela?

A: Tinha, mas já faz anos que não tem mais nada. Deu aquelas enchente tremenda, nem eu fiz de recordação, não tenho. E aqui são lugares que eu conheço, uma pena que não tem letreiro, eu gostava quando tirava assim na frente duma casa,do colégio, da escola, das aula..essa aqui também é parecida com...tudo aqui no Rio do Ouro?

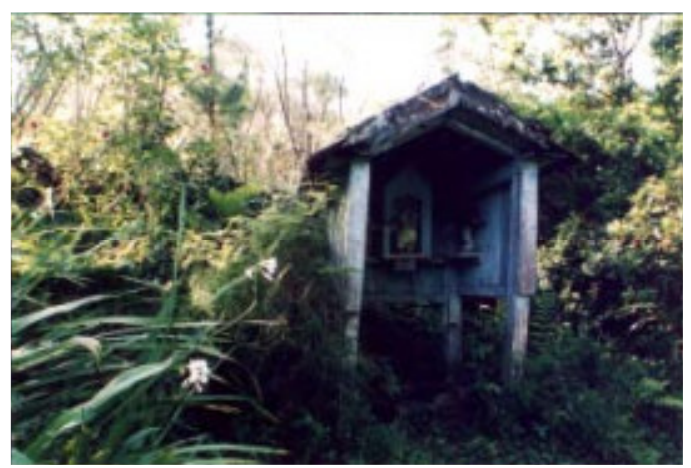

F: O senhor conhece essa casinha?

A: Essa aqui não é a igrejinha do Rio do Ouro? Essa aqui é...porque foi desmanchada a que eu me criei, desmancharam há pouco tempo, faz uns 2 anos, e fizeram nova, mas nem parecida não é. Essas aqui não é do meu tempo. Isso aqui é uma roça de milho...aqui é os milho que eles plantavam, importante lá que eles plantavam parreira, mas eu saí de lá foi em mi... não quero te dizer o dia errado...eu saí de lá dia vinte $\mathrm{e}$ sete de noventa e...mil novecento e noventa...dezenove de abril de noventa e sete.Que eu saí de lá foi nessa época. Agora eu to com, fiz esses dia setenta e oito...não é pouca coisa, né. Mas essa casa, por exemplo isso aqui não é uma coisa...seria importante pra uma pessoa que...trabalhar, tirar, meu Deus, quanto cento de fotografia eu já tirei, vendi, dei. 
Seu Arlindo saiu do Rio do Ouro ainda moço, perto dos vinte anos. Por isso talvez ele não se lembre tanto dos acontecimentos da linha. Mas ele tem uma memória fotográfica, reconhece as imagens com uma certa facilidade, ainda que elas sejam provavelmente, em ângulo, luz e enquadramento, diferentes das que ele fazia.

A: Olha não dá pra te dizer, de saída não to conhecendo nenhuma porque eu saí de lá, não é nada, não é nada, cinqüenta e dois anos...é muito tempo. Eu já foi em festa lá, até o dia que eu foi lá, a última festa que eu fui lá, mas infelizmente não pude tirar nenhuma foto. Ás nove e meia, dez horas escureceu o sol assim, e deu uma tromenta de chuva, com pedra, nem bater, de jeito nenhum. Não consegui bater nenhuma. Conhecer eu conheço, mas agora faz anos que não vou lá.
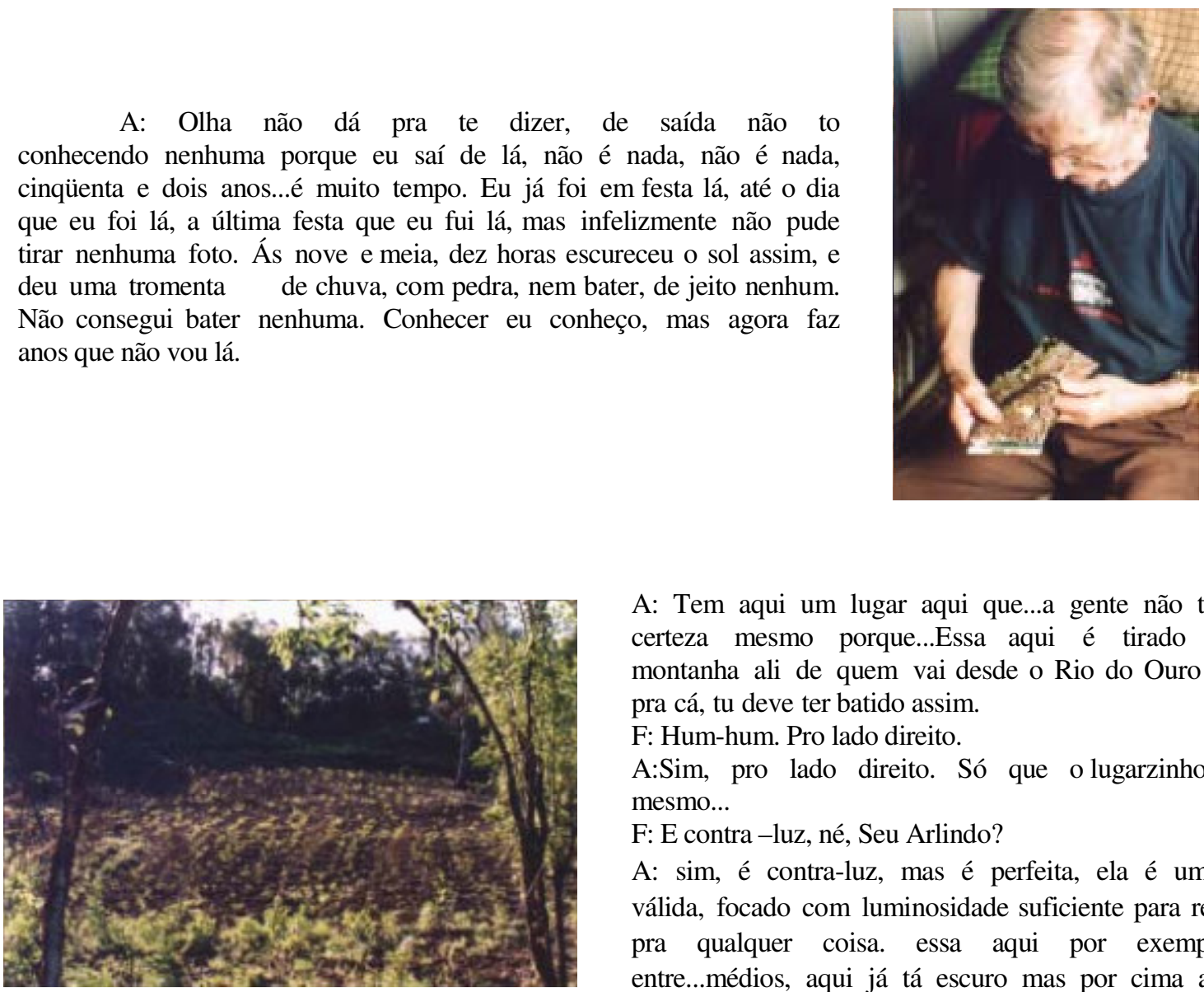

A: Tem aqui um lugar aqui que...a gente não tem uma certeza mesmo porque...Essa aqui é tirado com a montanha ali de quem vai desde o Rio do Ouro focando pra cá, tu deve ter batido assim.

F: Hum-hum. Pro lado direito.

A:Sim, pro lado direito. Só que o lugarzinho mesmo...

F: E contra -luz, né, Seu Arlindo?

A: sim, é contra-luz, mas é perfeita, ela é uma foto válida, focado com luminosidade suficiente para registrar pra qualquer coisa. essa aqui por exemplo ta entre...médios, aqui já tá escuro mas por cima aparece direitinho.

Enquanto Seu Arlindo olhava as fotos e tentava se lembrar de uma ou outra, me disse: 
Tu acredita que eu fui olhar depois até que vocês saíram eu passei um monte de foto velha, comida pelas traças, nenhuma foto da casa onde eu me criei e nasci não consegui mais. É incrível.

Na primeira visita que havia lhe feito, na companhia de dois amigos, perguntávamos a ele muitas coisas sobre seu passado. Seu Arlindo possui um bom acervo de fotos antigas, embora muitas ele afirma ter dado, vendido, perdido, até. Naquele dia, não nos mostrou as imagens, mas ficou de procurar e selecionar aquelas que segundo ele nos interessariam, para que quando retornássemos ele nos mostrasse seu trabalho. Ao final da conversa, ele não me mostrou, e eu não tornei a pedir. A única imagem do tempo antigo produzida por ele que cheguei a ver é a foto do incêndio da igreja da Barra do Ouro. Do tempo presente, guardo um retrato meu, feito por Arlindo Adamatti ao nos despedirmos.

\section{Pensando o tempo}

Mais do que a evocação de lembranças, o reconhecimento do tempo antigo nas imagens de hoje exigiu dos narradores uma acomodação do passado na paisagem que se faz presente. Enquanto viam as imagens, comentavam a passagem do tempo: as narrativas não eram de um passado que havia ficado para trás, mas de uma duração, onde passado e presente superpõe-se ritmicamente. O lembrar aqui, é uma forma de se pensar a duração. Para Gaston Bachelard (1994), a recordação prescinde de um apoio dialético no presente: não é possível reviver o passado sem que este seja encadeado num tema afetivo necessariamente presente. Nós não nos lembramos por simples repetição, mas por uma composição do passado.

Rocha e Eckert (2001), em consonância com as idéias de Bachelard e Piaget, concebem a memória como fruto de uma construção produtiva e criadora de conhecimento. Para as autoras, a memória é o resultado de uma hierarquia de instantes, configurando-se numa dialética da duração, isto é, a sobreposição rítmica de um tempo subjetivo e de um tempo do mundo (2001, p.35). Assim, pensar o tempo seria "propor que se viva de outro modo, que se retifique antes de tudo a vida e em seguida que se a enriqueça". 
O esquecimento pode ser uma forma de evitar esse pensar. As situações de mudança, quase sempre envolvem um sentimento de tristeza e perda, de desaparecimento. Nas palavras de Bachelard (1994, p. 38), "reviver o tempo desaparecido é assim aprender a inquietude de nossa morte".

No caso deste trabalho, proponho que a imagem fotográfica, na evocação de imagens passadas ou na tomada de consciência do presente, é uma forma de se pensar o tempo, não como um fenômeno objetivo, mas enquanto experiência temporal.

\section{Considerações Finais}

Se a questão da restituição da imagem e voz do Outro se coloca cada vez mais como fundamental na discussão sobre o uso da fotografia e dos recursos audiovisuais como um todo, o que parece estar também na pauta da discussão é uma marcada diferença que se coloca entre as sociedades/grupos tradicionais ou distantes da civilização da imagem, e a tecnologia que as mídias e os antropólogos dispõem. Como pude perceber neste trabalho, elas não são assim tão assustadoras como pressupunha antes de ir a campo, com a bagagem de leituras críticas ao consumo e à obtenção desmedidas da imagem do Outro. Ao contrário, e especialmente no que se refere à imagem, essas tecnologias exercem um fascínio sobre grupos e indivíduos que é humano e universal. Elas não constituem necessariamente uma ameaça às tradições, mas também uma forma de reconstituí-las, colocá-las na pauta das discussões e por que não, repensá-las.

O encontro entre as tecnologias globais e as tradições locais ainda causa estranheza: é comum pensar que um índio que possui uma câmera fotográfica ou que tem domínio de um recurso audiovisual a ponto de elaborar um vídeo acerca de sua própria imagem e cultura, está a um passo de perder sua identidade, se já não a perdeu. Entretanto, o domínio das tecnologias por parte de todos os povos é justamente uma forma de fazer ecoar suas identidades individuais e grupais. O fácil acesso à essas tecnologias nos indica um momento histórico onde a concentração de poder se desfaz, fragmentando-se em diversos segmentos da sociedade. Não é à toa que hoje aumentam as discussões sobre o estatuto da imagem. 
Isso não exclui, mas complementa a reflexão acerca da exclusão, ou da voluntária não adesão de algumas sociedades, grupos e indivíduos que de alguma forma permanecem distantes ou sem voz perante uma civilização da imagem. De fato, as mídias falam muito sobre os velhos, as crianças, os índios, os pobres, os negros, os analfabetos, mas poucas vezes a eles é dada a possibilidade de um discurso sobre a imagem de si mesmos.

A função de tradução que as mídias desempenham ao longo do tempo, pela própria veracidade atribuída aos recursos audiovisuais por ela utilizados, é legítima. Mas essa tradução não pode ser um discurso fechado, ao contrário, deve permanecer aberto e sensível àquilo que o Outro traduz por sua identidade. Transmitir a voz dos outros exige sensibilidade na percepção da demanda de dois extremos da cadeia comunicacional: o público e o grupo estudado. Assim como o jornalista, o antropólogo: não saber ver do ponto de vista do nativo, dialogar com ele e traduzir esse encontro a um terceiro público pode resultar em uma interpretação inadequada de um grupo e de sua cultura.

O presente trabalho foi uma tentativa de traduzir, trocar e restituir imagens à vida desses informantes/narradores da Barra do Ouro, levando em conta e refletindo sobre muitos dos aspectos que envolveram esse encontro entre "dois mundos": uma jovem de formação acadêmica e vinda de um grande centro urbano e velhos trabalhadores que vivem em uma pequena comunidade rural. As situações de campo que permearam essa pesquisa também se fazem presentes nos encontros travados pelos jornalistas com seus informantes, ainda que muitas vezes a rapidez e a objetividade dos contatos e das entrevistas possam encobrir essas situações.

A partir de um contato mais aproximado e permanente com essas pessoas, pude também repensar alguns aspectos da fotografia enquanto prática profissional. A situação deste trabalho me colocou entre dois fogos: a formação e a experiência cotidiana enquanto jornalista e as preocupações com a obtenção e o uso da imagem do Outro, suscitadas por um diálogo com a antropologia. Esse diálogo/confronto fez com que viessem à tona muitas das posturas por mim aqui criticadas no trabalho do jornalista, assim como uma excessiva preocupação com o uso que faria da imagem, na prática, nessa pesquisa. Enquanto fotógrafa, meu trabalho com a imagem e a relação com os sujeitos fotografados implicava 
em uma distância, da mesma forma que uma aproximação implicava em não fotografar. Eram posturas opostas caracterizavam por um lado, meu exercício profissional, onde não tinha nenhum vínculo com as pessoas que fotografava, e por outro meu trabalho de campo, que já construía suas bases em uma relação de afeto e confiança com as pessoas as quais iria fotografar.

A distância de que falo não é apenas física: podemos nos aproximar bastante da pessoa a ser fotografada sem estarmos com ela e com a tradução de sua imagem comprometidos. Essa distância fala de uma dificuldade em se chegar no Outro, posicionarse enquanto jornalista/antropólogo e buscar apreender seu ponto de vista.

Quando as imagens obtidas do Outro são colocadas à sua disposição ou ainda, quando essas imagens são produzidas conjuntamente entre antropólogos/jornalistas e indivíduos/grupos fotografados, no que o campo da antropologia chama "antropologia compartilhada", elas acabam por traduzir as escolhas e a criatividade do grupo no processo de reconstrução de sua memória, bem como a representação de suas identidades. Experiências onde as tecnologias de imagem e som são disponibilizadas a esses grupos resultam em trabalhos onde a vida de um grupo é mostrada com uma sinceridade impressionante. Entretanto, compartilhar a tecnologia com essas identidades sociais emergentes pode significar a dissolução ou uma profunda mudança nos rumos e no sentido dos trabalhos do antropólogo e do jornalista: quando as minorias são capazes de produzir suas próprias imagens, há necessidade de alguém que as traduza?

Enquanto a antropologia parece estar encontrando um caminho e uma preocupação com a restituição da imagem e da voz do Outro, a mídia encontra-se em uma situação paradoxal: ao mesmo tempo em que ganham força os trabalhos de pesquisa e documentação fotográfica ou textual, como o livro-reportagem, a imagem do Outro vem sendo cada vez mais "captada" e difundida. A discussão a respeito da ética e do direito à imagem ainda dá os seus primeiros passos e não envolve, necessariamente, a questão da restituição da imagem. O que se observa é que a discussão permanece no âmbito da recepção da imagem pelo leitor, e não de sua obtenção junto ao sujeito a ser fotografado.

Atentando à essas questões, cabe retificar a importância de um diálogo mais estreito entre as áreas da antropologia e do jornalismo, no sentido de compartilhar uma 
responsabilidade no trabalho de tradução e restituição da palavra do Outro. O jornalismo pode e deve se apropriar de conceitos caros à antropologia: as discussões da etnografia e do trabalho de campo não deixam de ser discussões sobre a ética de estar em campo e da tradução desse campo. A composição deste trabalho foi ela própria uma experiência de tradução entre dois campos: do jornalismo para a antropologia e vice-versa.

\section{REFERÊNCIAS}

ANAMA; PROGRAMA DE PÓS GRADUAÇÃO EM DESENVOLVIMENTO RURAL/UFRGS; PREFEITURA MUNICIPAL DE MAQUINÉ. Caracterização do Meio Rural do Município de Maquiné - RS: Subsídios para um Desenvolvimento Rural Sustentável. Relatório de pesquisa. Porto Alegre, 2000.

ARENDT, Hannah. Entre o passado e o futuro. São Paulo: Perspectiva, 1954. BACHELARD, Gaston. A dialética da duração. São Paulo: Editora Ática, 1994.

BARROS, Myriam Lins de. Autoridade \& Afeto: avós, filhos e netos na família brasileira. Rio de Janeiro: Jorge Zahar Editor, 1987.

BERTUSSI, Paulo Iroquez. Elementos de arquitetura da imigração italiana. In: WEIMER, Günter (org). A arquitetura no Rio Grande do Sul. Porto Alegre: Mercado Aberto, 1983.

BENJAMIN, Walter. Magia e técnica, arte e política. São Paulo: Brasiliense, 1994.

BITTENCOURT, Luciana Aguiar. Algumas considerações sobre o uso da imagem fotográfica na pesquisa antropológica. In: Desafios da Imagem, fotografia, iconografia e vídeo nas ciências sociais. Campinas: Papirus, 1998.

BOSI, Ecléa. Memória e Sociedade, lembranças de velhos. São Paulo: Companhia das Letras, 1994.

BUCCI, Eugênio. Sobre Ética e Imprensa. São Paulo: Companhia das Letras, 2000.

CALDEIRA, Teresa Pires do Rio. Uma incursão pelo lado "não-respeitável" da pesquisa de campo. Texto apresentado no IV Encontro Anual da ANPOCS. Rio de Janeiro, 1980.

CAUDURO, Flávio. Fotografia digital. In: ACHUTTI, Luiz Eduardo Robinson. Ensaios sobre o fotográfico. Porto Alegre: Unidade Editorial, 1998.

DAMATTA, Roberto. O Ofício do Etnólogo ou como Ter 'Antropological Blues'. In: Boletim do Museu Nacional, Rio de Janeiro, 1978.

DINIZ, Ariosvaldo da Silva. A iconografia do medo ( Imagem, imaginário e memória da cólera do século XIX). In: KOURY, Mauro Guilherme Pinheiro (org). Imagem e Memória, ensaios em antropologia visual. Rio de Janeiro: Garamond, 2001.

DUBOIS, Philippe. O ato fotográfico. Campinas: Papirus, 1993.

ELIAS, Norbert; SCOTSON, John L. Os Estabelecidos e os Outsiders. Rio de Janeiro: Jorge Zahar Editor, 2000.

FLUSSER, Vilém. Ensaio sobre a fotografia, para uma filosofia da técnica. Lisboa: Relógio

D’Água Editores, 1998.

GALLOIS, Dominique T.; CARELLI, Vicent. Vídeo e diálogo cultural - Experiências do Projeto Vídeo nas Aldeias. In: ECKERT, Cornelia; GODOLPHIM, Nuno (org). Horizontes Antropológicos, n 2. Antropologia Visual. Porto Alegre: Programa de Pós Graduação em Antropologia Social da Universidade Federal do Rio Grande do Sul, 1995. 
GEERTZ, Clifford. Obras e Vidas. O antropólogo como autor. Rio de Janeiro: Editora UFRJ, 2002.

GERHARDT, Clayton Henrique. Agricultores familiares, mediadores sociais e meio ambiente: A construção da problemática ambiental em agro-eco-sistemas. Porto Alegre, 2002. Dissertação de Mestrado (Programa de Pós-Graduação em Desenvolvimento Rural, Universidade Federal do Rio Grande do Sul).

GURAN, Milton. Linguagem fotográfica e informação. Rio de Janeiro: Rio Fundo Editora, 1992.

GURAN, Milton.. Fotografar para descobrir, fotografar para contar. In: Cadernos de Antropologia e Imagem n10. Rio de Janeiro: 2000.

GURAN, Milton.. A "fotografia eficiente" e as Ciências Sociais. In: Achutti, Luiz Eduardo Robinson. Ensaios sobre o fotográfico. Porto Alegre: Unidade Editorial, 1998.

HALBWACHS, Maurice. A memória coletiva. São Paulo: Vértice, Editora Revista dos Tribunais, 1990.

KOSSOY, Boris. Fotografia e história. São Paulo: Editora Ática, 1989.

LEITE, Miriam Moreira. Retratos de Família. São Paulo: Edusp, 2001.

MARESCA, Sylvain. Sobre os desafios lançados pela fotografia às Ciências Sociais. In:

ACHUTTI, Luiz Eduardo Robinson. Ensaios sobre o fotográfico. Porto Alegre: Unidade Editorial, 1998.

PAIVA, Joaquim. Olhares Refletidos. Rio de Janeiro: Dazibao, 1989.

POSENATO, Júlio. Arquitetura da imigração italiana no Rio Grande do Sul. Porto Alegre:

Fondazione Giovani Agnelli, 1983.

ROCHA, Ana Luiza Carvalho da; ECKERT, Cornelia. Imagens do tempo nos meandros da memória: por uma etnografia da duração. In: KOURY, Mauro Guilherme Pinheiro (org). Imagem e Memória, Ensaios em Antropologia Visual. Rio de Janeiro: Garamond, 2001.

ROCHA, Ana Luiza Carvalho da; ECKERT, Cornelia.. Cidade e Tempo. Porto Alegre: Editora da UFRGS, no prelo.

SOUSA, Jorge Pedro. Uma história crítica do fotojornalismo ocidental. Chapecó: Grifos, 2000.

THOMPSON, Paul. A voz do passado. Rio de Janeiro: Paz e Terra, 1992.

VELHO, Gilberto. Individualismo e Cultura. Rio de Janeiro: Jorge Zahar Editor, 1997.

VELHO, Gilberto.. Projeto e metamorfose: antropologia das sociedades complexas. Rio de Janeiro: Jorge Zahar Editor, 1994.

VELHO, Gilberto.. Biografia, trajetória e mediação. In: VELHO, Gilberto;

KUSCHNIR, Karina (orgs). Mediação, cultura e política. Rio de Janeiro: Aeroplano Editora, 2001. WINKIN, Yves. A nova comunicação. Campinas: Papirus, 1998 